\title{
Crustal shortening at the Sierra Pie de Palo (Sierras Pampeanas, Argentina): near-surface basement folding and thrusting
}

\author{
N. BELLAHSEN*†, M. SEBRIER* \& L. SIAME \\ * Sorbonne Universités, UPMC Université Paris 06, CNRS, Institut des Sciences de la Terre de Paris (iSTeP), 4 place \\ Jussieu, 75005 Paris, France \\ †Aix-Marseille Université, CNRS - IRD - Collège de France, UM34 Centre Européen de Recherche et d'Enseignement \\ des Géosciences l'Environnement, Technopôle de l'Arbois, Aix-en-Provence, France
}

(Received 11 December 2015; accepted 3 May 2016)

\begin{abstract}
The Sierras Pampeanas consist of basement uplifts that are mainly controlled by W-verging crustal thrusts. One of these, the Sierra Pie de Palo, is controlled by a blind thrust whose kinematics is debated. We analysed the reverse faults located along the eastern side of the range and show that these are characterized by small displacements (few hundreds of metres) of the Neogene and Quaternary deposits controlled by the inherited basement metamorphic foliation and shear zones. At the sierra scale, the inherited foliation pattern appears already folded, before the Cenozoic shortening, forming a series of antiforms and synforms with various wavelengths. We propose that this structure is amplified during the Plio-Quaternary shortening, resulting in a large asymmetrical basement-cored anticline where foliation-parallel slip can act as folding mechanism. The overall kinematics is consistent with an E-verging fault-propagation fold; this proposed kinematics is an alternative to the frequently suggested W-verging fault-bend fold model. Finally, we propose a new, alternative and speculative crustal and lithospheric structure for this region consisting of two E-verging basement thrusts coeval to W-verging Pampean thrusts, both rooting below the Precordillera, above an eclogitized lower crust.
\end{abstract}

Keywords: Sierras Pampeanas, Andes, thick-skinned tectonics, structural inheritance, folding.

\section{Introduction}

In the upper crust, deformation usually localizes on major faults because of the frictional mechanical behaviour and strain weakening active in the crust (e.g. Collettini et al. 2009). A notable exception is the sedimentary cover that has the ability to fold mainly because of the mechanical stratigraphy with weak, low-stress interbeds. Thus, in contractional setting, sedimentary cover usually deforms with typical fold-and-thrust belt kinematics. In the basement, however, mainly composed of crystalline rocks, the deformation is more localized than in the sedimentary cover. Only approaching the brittle-ductile transition, and below, is the deformation distributed, mainly due to temperature increase.

Thus, for basement rocks in the upper crust up to the surface, our understanding of crustal rheology will predict localized, major faults. In some cases, however, the deformation is seen as more distributed in the field. This distributed, though brittle, deformation has been observed at a few places, mainly in the Laramide Orogenic belt (Rocky Mountains), as well as in South America: it is interpreted either as basement deformation over a fault-bend fold (Casas et al. 2003) or in a fault-propagation fold with triangular zones of shear ahead of or near the thrust upper tip (Erslev, 1991;

$\dagger$ Author for correspondence: nicolas.bellahsen@upmc.fr Original article submitted to the special issue: 'Tectonic evolution and mechanics of basement-involved fold-and-thrust belts'
Schmidt, Genovese \& Chase, 1993; Bump, 2003; Garcia \& Davis, 2004; Beaudoin et al. 2012).

The Sierras Pampeanas (Fig. 1), a modern analogue of the Laramide Rocky Mountains (Jordan \& Allmendinger, 1986), provide a unique setting for studying basement deformation in a shallow brittle setting. The Sierra Pie de Palo (Figs 1, 2, 3) is a basement uplift in the Sierras Pampeanas, NW Argentina. It is topped by a $3000 \mathrm{~m}$ high perched erosional surface that attests for a significant structural relief. This structure is interpreted either as a fault-bend fold on a W-verging thrust (Ramos, Cristallini \& Pérez, 2002; Vergés et al. 2007) or as a fold above an E-verging blind thrust that branches at depth on a W-verging thrust (Siame et al. 2002, 2015; Siame, Bellier \& Sebrier, 2006). In both cases, these models imply some distributed deformation in the basement that necessitates a detailed study.

Thanks to excellent outcrop conditions in the Pie de Palo area, we combined structural and microstructural observations along its eastern margin and available data to propose a model for basement folding integrating outcrop- and crustal-scale interpretations. In particular, we propose that, in the uppermost crust, the shortening, localized on inherited foliation planes that folded and evolved as cataclastic faults, may have allowed folding of the upper crust above an E-verging blind thrust. We propose new cross-sections at crustal and lithospheric scale that are consistent with the geological and geophysical data and constitute an alternative 

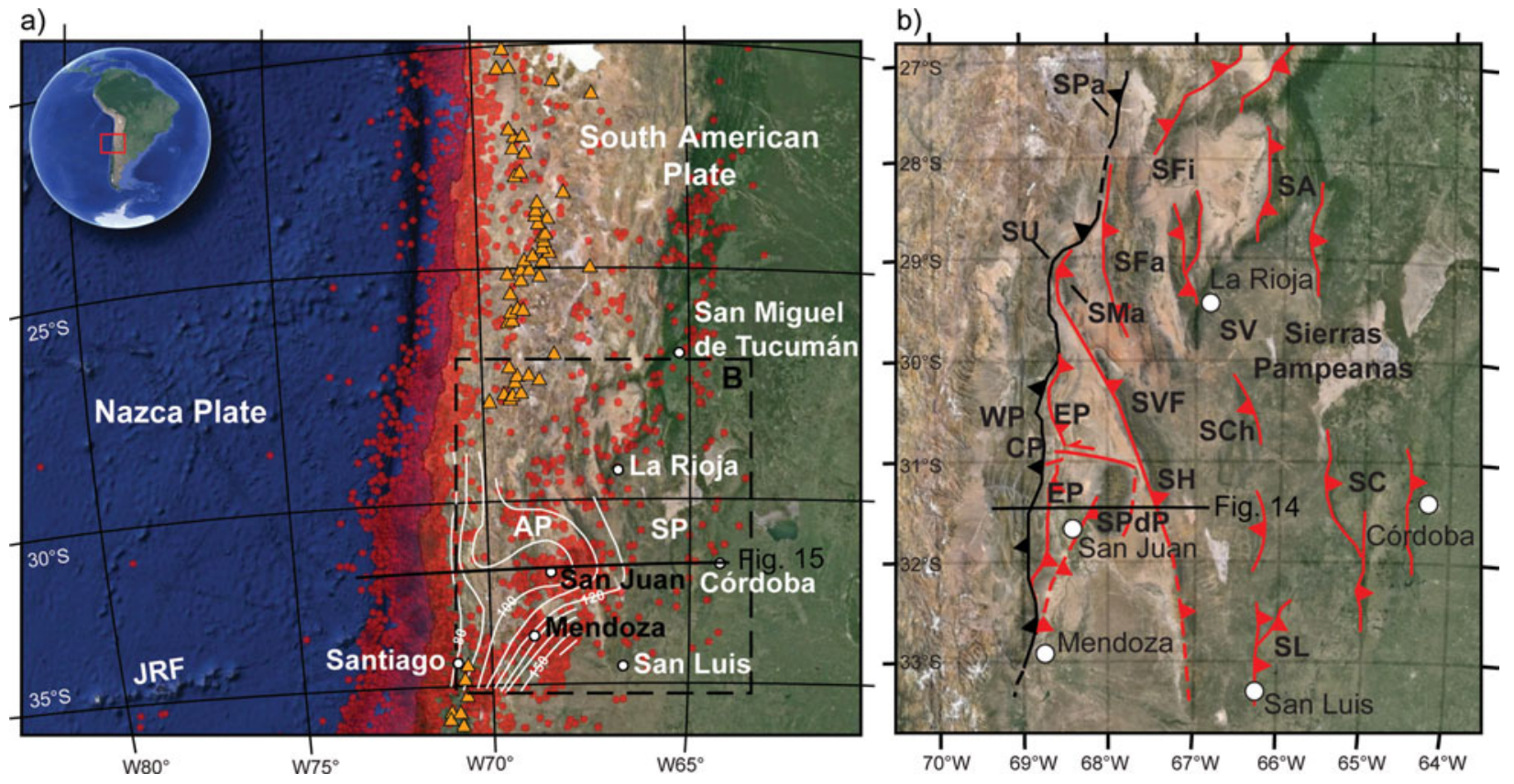

Figure 1. (Colour online) (a) Map of Central Andes (Landsat images and General Bathymetric Charts of the Oceans) together with distribution of active volcanoes (orange solid triangles, Smithsonian Institution, Global Volcanism Program) and seismicity (red solid dots, US Geological Survey seismicity catalogue, $M \geq 4.0$ and depth $\leq 70 \mathrm{~km}$ ). White solid lines (labelled in $\mathrm{km}$ ) are isodepths of the Wadati-Benioff plane and highlight the Pampean flat slab of the Nazca plate (after Ammirati et al. 2013). Key: AP, Argentine Precordillera; SP, Sierras Pampeanas; JRF, Juan Fernandez Ridge. (b) Schematic regional structural map of the Sierras Pampeanas. Red solid lines denote active structures. Key: AP, Argentine Precordillera; WP, Western Argentine Precordillera; CP, Central Argentine Precordillera; EP, Eastern Central Precordillera; SPDP, Sierra Pie de Palo; SH, Sierra de la Huerta; SVF, Sierra de Valle Fértil; SMa, Sierra La Maz; SFa, Sierra de Famatina; SFi, Sierra Fiambala’ SA, Sierra Ambato; SV, Sierra Velasco; SCh, Sierra Chepes; SC, Sierra de Còrdoba; SL, Sierra San Luis; SU, Sierra Umango; SPa, Sierra de las Planchadas.

model for Andean shortening in the specific Andean backarc province (Cuyania crust).

\section{Regional setting of the Sierras Pampeanas}

The Pie de Palo anticline is one of the Sierras Pampeanas ranges that extend between $27^{\circ}$ and $33^{\circ} \mathrm{S}$ and $64^{\circ}$ and $68^{\circ} \mathrm{W}$ (Fig. 1b). These $\sim \mathrm{N}$-striking ranges (NNW to NNE) correspond to Neogene-Quaternary basement-block uplifts, which are located to the east of the Andes (Fig. 1). These basement blocks extend where the Nazca slab, which is subducting eastward below the western edge of the South American plate, flattens below the Andes at a depth of $\sim 100 \mathrm{~km}$ (Jordan et al. 1983; Jordan \& Allmendinger, 1986; Cahill \& Isacks, 1992; Ramos, Cristallini \& Pérez, 2002; Anderson et al. 2007). This segment of the Andean subduction is characterized by a $\sim \mathrm{N} 75^{\circ} \mathrm{E}$-trending convergence with a rate of $c .75 \mathrm{~mm} \mathrm{a}^{-1}$ (DeMets et al. 1990). The flat slab geometry appears to result from the subduction of the Juan Fernandez aseismic ridge (Fig. 1a), which increases the buoyancy of the Nazca plate (Pilger, 1981; Gutscher et al. 2000). This ridge subduction initiated between 14 and $11 \mathrm{Ma}$, moving from north to south along the Chilean trench (Yanez et al. 2001). The volcanic arc migrated eastward from $\sim 11 \mathrm{Ma}$ to $\sim 8$ Ma to shut off totally by $5 \mathrm{Ma}$ (Kay \& Mpodozis, 2002), and the flat geometry reached the retroarc region between Late Miocene and Pliocene (Kay \& Abbruzzi,
1996). Indeed, Andean regions with flat slab subduction (e.g. Central Peru and Sierras Pampeanas) are commonly characterized by an extinct volcanic arc and display a much wider shortening retroarc belt because it should accommodate larger amounts of shortening than the neighbouring regions characterized by steeper slabs (Jordan et al. 1983; Sebrier et al. 1988). This shortening deformation is also possibly enhanced by thermal weakness of the crust associated with the eastward migration of the asthenospheric wedge (Ramos, Cristallini \& Pérez, 2002).

The $27-33^{\circ} \mathrm{S}$ retroarc shortening province associated with the Andean flat slab segment comprises two main parts (Fig. 1b): (1) a $\sim 40 \mathrm{~km}$ narrow, Everging, thin-skinned, fold-and-thrust belt composed of Palaeozoic-Mesozoic rocks and extending to the east of the main high Andes from Sierra de Las Planchadas $\left(27.5^{\circ} \mathrm{S}\right)$ up to the southern Precordillera in the Mendoza area $\left(33^{\circ} \mathrm{S}\right)$ and $(2) \mathrm{a} \sim 350 \mathrm{~km}$ wide subprovince of mostly W-verging block uplifts made of Precambrian and early Palaeozoic metamorphic rocks, i.e. the Sierras Pampeanas. Overall, the E-verging thin-skinned thrusts initiated earlier (Early to Mid Miocene) than the Pampean basement uplifts, which started between the Late Miocene in the northern Sierras Pampeanas and the Pliocene-Quaternary in the southern ones (Jordan et al. 1993; Zapata \& Allmendinger, 1996). Indeed, these basement uplifts are located within the distal part of the Miocene foreland basin as out-of-sequence 


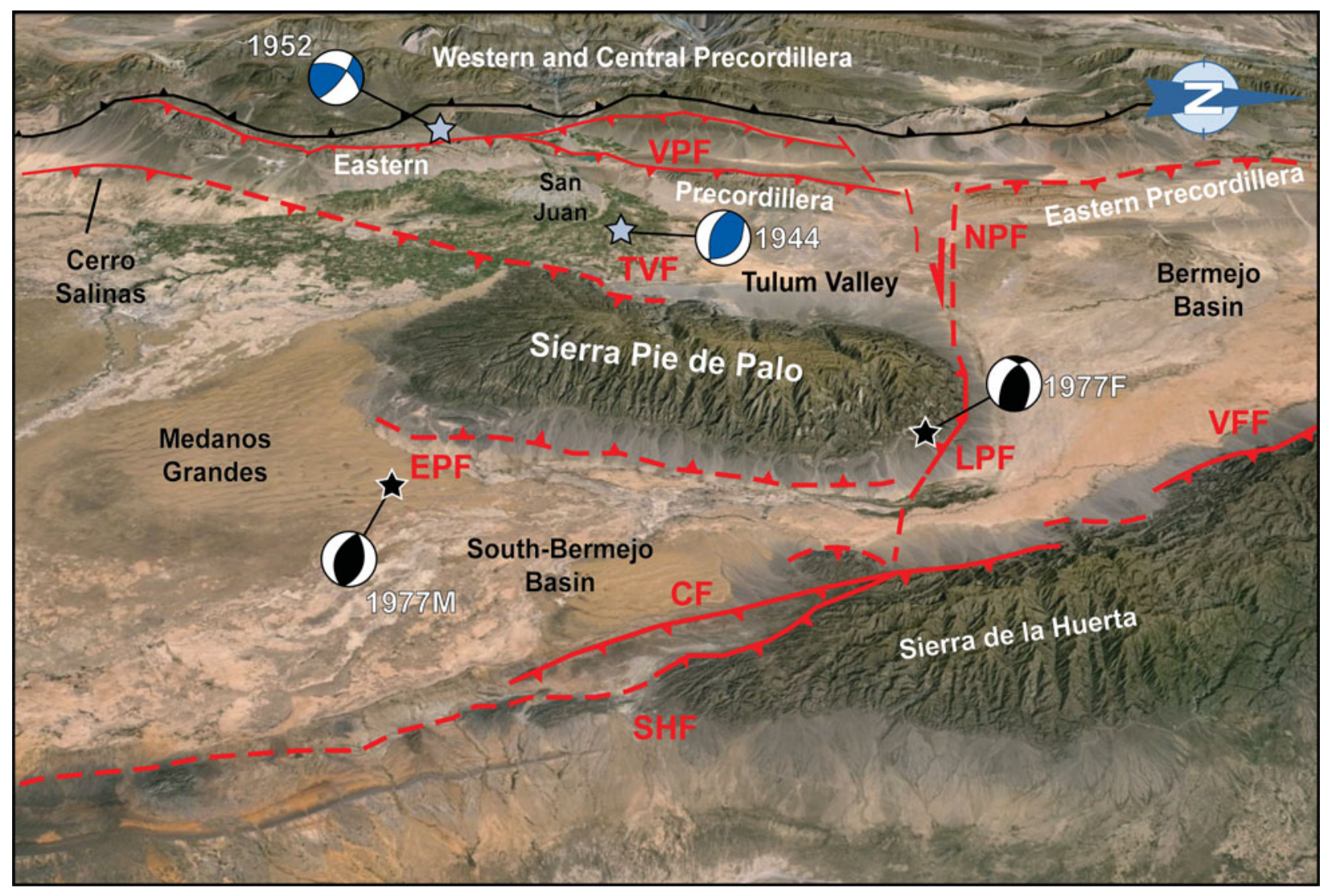

Figure 2. (Colour online) Tentative schematic structural map of the Sierra Pie de Palo and surroundings showing the major faults. Modified after Siame et al. (2015). CF, Las Chacras Fault; EPF, East Pie de Palo Fault; LPF, Los Pajaritos Fault; NPF, North Pie de Palo Fault; SHF, Sierra de la Huerta Fault; TVF, Tulum Valley Fault; VFF, Valle Fértil Fault; VPF, Villicùm-Pedernal Fault. The dashed line east of the Pie de Palo is the limit between alluvial fans and the flat playa type of Quaternary sediments. Its linear geometry suggests that the alluvial fans are slightly tilted; this should be controlled by the blind E-verging thrust. Indeed, the older fan surfaces are steeper than the younger ones (the older the fan, the steeper its surface). Light blue stars locate $1944\left(M_{\mathrm{w}}=7.0\right)$ and $1952\left(M_{\mathrm{w}}\right.$ $=6.8$ ) earthquakes with focal mechanism solutions after Alvarado and Beck (2006). Black stars locate fore- and main shocks of the Caucete $1977\left(M_{\mathrm{s}}=7.4\right)$ earthquake (focal mechanism solutions after Langer \& Hartzell, 1996).

faulted blocks so that this foreland is generally described as a broken foreland (Jordan et al. 1983). Typically, the sedimentary signature of these uplifts is the onset of conglomerate deposits atop the previous thin distal sedimentation (Jordan et al. 1993). These blocks uplifts are controlled by the reactivation of inherited crustal weaknesses, such as Proterozoic or Early Palaeozoic sutures and Late Palaeozoic or Mesozoic graben normal faults (Ramos, Cristallini \& Pérez, 2002), which explain their variable lengths from several tens to several hundreds of kilometres. Interestingly, the Pampean ranges have a wide range of altitudes between $\sim 1000$ and $6000 \mathrm{~m}$, with a mean tendency to higher elevations northward and westward, which may result both from an earlier northern initiation and a larger amount of shortening closer to the Andes.

The area of interest is located on the $\sim 400 \mathrm{~km}$ wide south-central profile of the Sierras Pampeanas $\left(\sim 31.5^{\circ} \mathrm{S}\right)$, which extends approximately between the cities of San Juan and Còrdoba (Fig. 1b). Adding the $\sim 50 \mathrm{~km}$ wide, thin-skinned fold-and-thrust belt yields a width of $\sim 450 \mathrm{~km}$ for the Neogene-to-present retroarc shortening province. This central profile offers the fol- lowing characteristics: (1) it is located just above the central part of the flat slab segment (Anderson et al. 2007), (2) it has been the focus of many geological studies (Ramos, Cristallini \& Pérez, 2002 and references therein), particularly in its western stretch where most of the shortening is accommodated, (3) the Neogene to present history of shortening is relatively well constrained to $90 \mathrm{~km}$, yielding a regional mean rate of $4.5 \mathrm{~mm} \mathrm{a}^{-1}$ during the last $20 \mathrm{Ma}$ (Allmendinger et al. 1990; Jordan, Schlunegger \& Cardozo, 2001), and (4) the level of crustal seismicity is the highest along this profile in the whole retroarc belt (Smalley et al. 1993; Siame et al. 2005). Consequently, many seismological studies provide information on the crustal seismicity (Kadinsky-Cade \& Reilinger, 1985; Regnier et al. 1992; Smalley et al. 1993; Alvarado et al. 2005, 2009; Alvarado \& Beck, 2006; Alvarado, Beck $\&$ Zandt, 2007) and the lithospheric and crustal structures (Ammirati, Alvarado \& Beck, 2015 and references therein). The main results obtained along this profile are summarized hereafter. The eastward cessation of volcanism in the Central Precordillera $\left(68.8^{\circ} \mathrm{W}\right)$ by $7 \mathrm{Ma}$ and in the Sierra de Còrdoba $\left(65.2^{\circ} \mathrm{W}\right)$ by 4.7 Ma (Kay \& Abbruzzi, 1996) demonstrates that the flat 


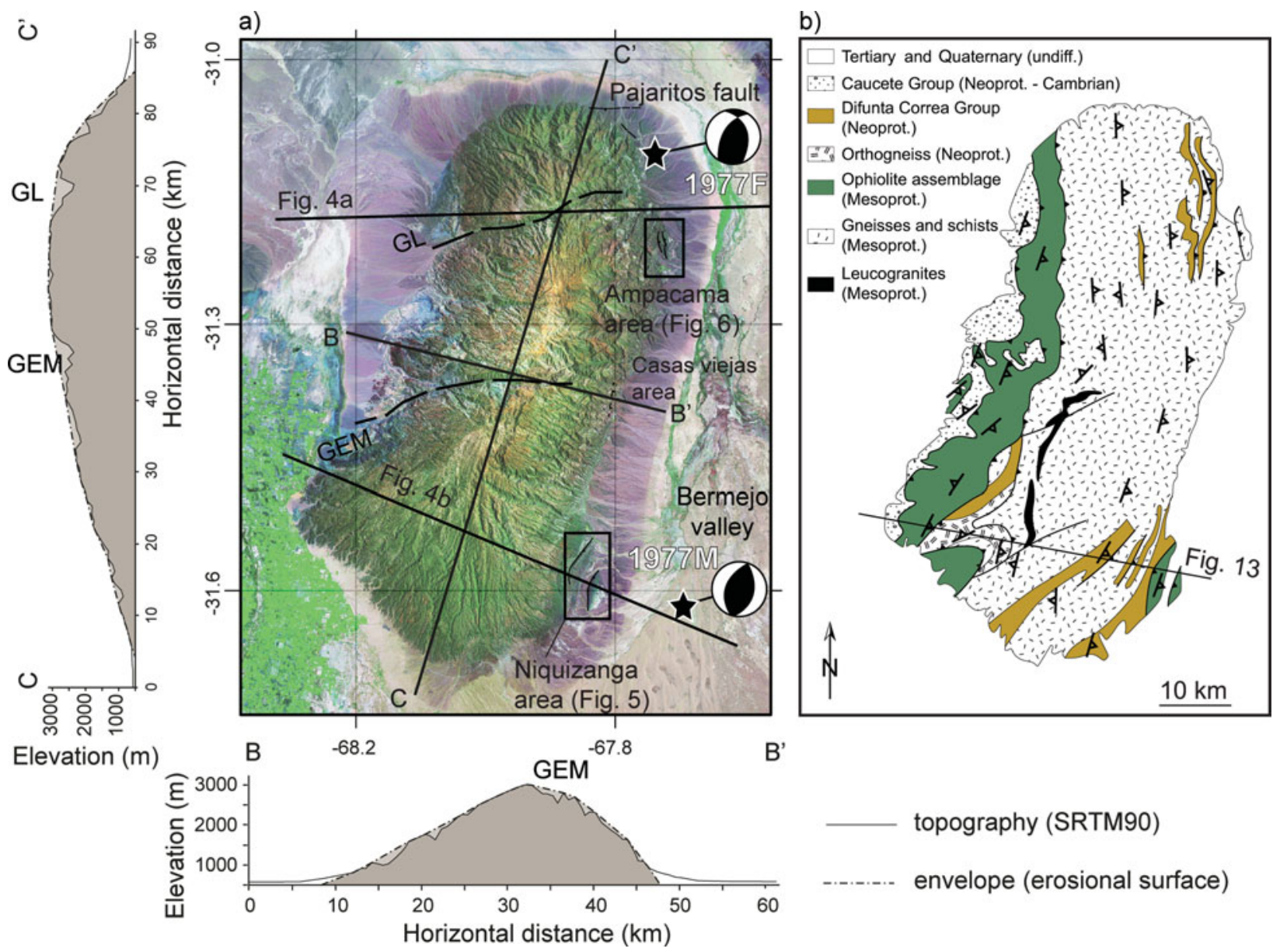

Figure 3. (Colour online) (a) Landsat image of the Sierra Pie de Palo. Both $\approx \mathrm{E}-\mathrm{W}\left(\mathrm{B}-\mathrm{B}^{\prime}\right)$ and $\approx \mathrm{N}-\mathrm{S}\left(\mathrm{C}-\mathrm{C}^{\prime}\right)$ topographic cross-sections have been extracted from the Shuttle Radar Topography Mission 1990 digital elevation model (SRTM90 DEM) (thick solid lines). The reconstructed regional erosion surface (thick dotted lines) is after Siame et al. (2015). The two stars locate the two 1977 earthquakes with their respective focal solutions (F for fore shock and M for main shock) (Langer \& Hartzell, 1996). Key: GEM, Grande El Molle lineament; GL, Guayaupa-Lima lineament. (b) Geological map with main foliation orientations modified from Ramos and Vujovich (2000), Mulcahy et al. (2011) and Van Staal et al. (2011).

slab geometry was installed below this profile between the Late Miocene and the Early Pliocene. The depth of the continental Moho varies along this profile: $66 \mathrm{~km}$ below the Central Precordillera (Ammirati et al. 2013), $52 \mathrm{~km}$ below the Sierra Pie de Palo (Calkins et al. 2006; Ammirati, Alvarado \& Beck, 2015), while it is only $38 \mathrm{~km}$ and $35 \mathrm{~km}$ below the western and eastern parts of the Sierra de Cordoba, respectively (Perarnau et al. 2012). The highest level of seismicity (Smalley et al. 1993) is located between the Central Precordillera $\left(68.8^{\circ} \mathrm{W}\right)$ and the Sierra del Valle Fértil - La Huerta $\left(67.3^{\circ} \mathrm{W}\right)$; the base of this crustal seismicity appears deeper than $30 \mathrm{~km}$ and might correspond to a $\sim 34 \mathrm{~km}$ deep seismic discontinuity, while a shallower one is also observed at a depth of $\sim 18 \mathrm{~km}$ (Calkins et al. 2006; Alvarado, Beck \& Zandt, 2007; Ammirati, Alvarado \& Beck, 2015). This seismic discontinuity near the base of the crustal seismicity could correspond to the main Andean décollement that permits eastward propagation of the Andean shortening to the Sierra Pampeanas. Interestingly, the GPS velocity field measured in this high-seismicity zone suggests a step in their eastward decay that may agree with a shortening rate of $\sim 5 \mathrm{~mm} \mathrm{a}^{-1}$ (Brooks et al. 2003). Three destructive earthquakes with $M_{\mathrm{w}} \sim 7$ occurred within this region in 1944, 1952 and 1977. The first two had focal depths of $11 \mathrm{~km}$ and $12 \mathrm{~km}$, respectively (Alvarado \& Beck, 2006), while the 1977 focus was estimated at $\sim 25-30$ km (Alvarado \& Beck, 2006 and references therein).

Finally, one important consequence of the slab geometry is the decrease in the thermal gradient in the overlying continental crust. Thermal modelling indicates a thermal lowering from $\sim 30^{\circ} \mathrm{C} \mathrm{km}^{-1}$ (situation above steeper Andean subduction segments) to $\sim 10^{\circ}$ $\mathrm{km}^{-1}$ for the flat segments caused by the lack of asthenospheric wedge (Gutscher et al. 2000). This low thermal gradient has been determined within the sediments of the Neogene basins (Collo et al. 2015) and explains why thermo-chronologic studies have major difficulties constraining the uplift rates of most of the Western Pampean ranges (Davila \& Carter, 2013), especially along the central profile of the Sierras Pampeanas (Löbens et al. 2013). Obviously, this also agrees quite well with the uncommonly deep crustal seismicity observed in the region (Regnier et al. 1992; Smalley et al. 1993). 


\section{Geological setting of the Sierra Pie de Palo}

The NNE-striking, oval-shaped Sierra Pie de Palo (Figs 2, 3) is located at $31.4^{\circ} \mathrm{S}, 67.9^{\circ} \mathrm{W}$. It is $80 \mathrm{~km}$ long and $32 \mathrm{~km}$ wide, and has an altitude of $3162 \mathrm{~m}$, towering above the surrounding $500-600 \mathrm{~m}$ elevated desert alluvial plain. This range is bounded by (Fig. 2): to the west, the Tulum Valley, a syncline of Neogene and Quaternary beds, which separates the Sierra Pie de Palo from the Eastern Precordillera; to the north, the $10 \mathrm{~km}$ thick Neogene to Quaternary Bermejo foreland basin; to the east, the triangular-shaped South Bermejo Valley, which is a Neogene to Quaternary synclinorium basin separating the Sierra Pie de Palo from the NNW-striking Sierra Valle Fértil - La Huerta range; and to the south, the southern continuation of the Bermejo basin which stands below the Medanos Grandes sand dunes. The first-order topography of the Sierra Pie de Palo (Fig. 3a) corresponds to a dissymmetric arch with steep eastern and northern slopes whereas the southern and western slopes are gently dipping (Siame, Bellier \& Sebrier, 2006; Siame et al. 2015). The western long limb of the range is dissected by two main WSW-striking, rectilinear, deep canyons Guayaupa-Lima and Grande El Molle (Fig. 3). However, topographic profiles along the top of the range do not reveal any significant vertical displacement associated with these transverse lineaments. Similarly, they do not displace the rectilinear eastern front of the Pie de Palo range, hence they should be presently inactive structures (Siame et al. 2015).

The relatively flat areas composing the Sierra Pie de Palo range topography define a convincing surface envelope along both $\mathrm{N}-\mathrm{S}$ and $\mathrm{E}-\mathrm{W}$ directions (Fig. 3), shaping an anticline fold (Siame et al. 2015). These flat surfaces are characteristic of most of the Sierras Pampeanas and have long been referred to as the 'Pampean peneplain' (Jordan et al. 1989). This 'peneplain' appears polygenic as it formed between Middle Palaeozoic and Cretaceous times (Carignano, Cioccale \& Rabassa, 1999; Costa et al. 2000; Rabassa, Carignano \& Cioccale, 2010). However, the main debate concerns the timing of its exhumation. Some considered this erosion surface was mostly deformed and exhumed during the Neogene (e.g. Jordan et al. 1989) while others proposed that the Sierras Pampeanas may have been exhumed since the Late Palaeozoic or Mesozoic (Carignano, Cioccale \& Rabassa, 1999; Rabassa, Carignano \& Cioccale, 2010; Löbens et al. 2011, 2013; Enkelmann et al. 2014). In the Sierra Pie de Palo range, the age of this surface is quite imprecise as it is cutting on basement metamorphic rocks of Early Palaeozoic - Proterozoic age (Ramos \& Vujovich, 2000) and covered around the range by Neogene continental deposits. These red-beige deposits correspond at the SE edge of the Pie de Palo range to the $300 \mathrm{~m}$ thick Niquizanga Formation and the overlying $420 \mathrm{~m}$ thick Río del Camperito Formation (Cuerda, Varela \& Iniguez, 1983). These two formations are correlated with the Upper Miocene - Lower Pliocene Jachal and Pliocene-
Quaternary Mogna Formations, respectively; these are dated in the Bermejo basin to the north of the Pie de Palo range (Jordan et al. 1993; Zapata \& Allmendinger, 1996). The Niquizanga Formation, which rests directly upon the 'Pampean peneplain', is composed of thin clastic lacustrine beds containing evaporite facies (halite and gypsum), suggesting that the Neogene topography of the Sierra Pie de Palo range was either very subdued or even almost non-existent at that time so that the 'Pampean peneplain' could have been completely covered by the Neogene beds of the Bermejo foreland basin. The thickness of the Neogene beds might have totalled 2-3 km at most (e.g. Ramos \& Vujovich, 2000) and more likely $1.9-2.4 \mathrm{~km}$ (Siame et al. 2015). The first option agrees with a long history of exhumation whereas the second favours a late Cenozoic rapid exhumation. Whatever the initial thickness of Neogene deposits above the 'Pampean peneplain', recent cosmogenic nuclide data $\left({ }^{10} \mathrm{Be}\right)$ favour a rapid uplift of the Pie de Palo anticline during the last 2-4 Ma (Siame et al. 2015). Furthermore, the low thermal gradients reported in the Neogene basins (Davila \& Carter, 2013; Collo et al. 2015) also indicate that the Pliocene-Quaternary folding and uplift of the metamorphic basement must have occurred under near-surface conditions.

The Sierra Pie de Palo range is an actively growing basement anticline associated with a high level of crustal seismicity (Regnier et al. 1992; Smalley et al. 1993; Ramos, Cristallini \& Pérez, 2002; Siame et al. 2002, 2015; Siame, Bellier \& Sebrier, 2006). This range is bounded by three major faults. The northern boundary of the range corresponds to the North Pie de Palo fault, a $\sim \mathrm{E}-\mathrm{W}$-striking transpressive, left-lateral fault, which extends over $80 \mathrm{~km}$ from the Matagusanos basin, south of the Mogna anticline in the Eastern Precordillera (Zapata, 1998), to the Sierra Valle Fértil fault (Fig. 2). This regional structure also controls a major northward deepening in the basement depth across the southern boundary of the Bermejo basin (Jordan \& Allmendinger, 1986). It limits the northern edge of the Sierra Pie de Palo along c. $26 \mathrm{~km}$, roughly at the contact between the metamorphic basement and the Neogene and Quaternary deposits. This stretch, which is referred as the Pajaritos Fault (Fig. 3) (Costa et al. 2000), displays fairly rectilinear $\mathrm{N}$-facing scarp traces that are quite conspicuous at two locations $\left(31.047^{\circ} \mathrm{S}\right.$, $67.94^{\circ} \mathrm{W}$ and $\left.31.057^{\circ} \mathrm{S},-67.84^{\circ} \mathrm{W}\right)$. The easternmost location of this Pajaritos Fault affects a series of alluvial fans and exhibits a well-developed $4 \mathrm{~km}$ long, northfacing fault scarp with a right-stepping relay agreeing with some left-lateral component of slip associated with a steep $\left(45-60^{\circ} \mathrm{S}\right.$ dipping) reverse movement. This $\mathrm{Pa}-$ jaritos Fault was interpreted as a lateral ramp of the Pie de Palo anticline, and its reverse slip rate determined to $\sim 1 \mathrm{~mm} \mathrm{a}^{-1}$ (Siame et al. 2015).

The western boundary of the Pie de Palo metamorphic basement with the Tulum Valley syncline is very sinuous and the Quaternary bordering alluvial deposits form a very poorly incised series of fans. All these landform features suggest that no fault activity is 
occurring along this western edge of the range. Nevertheless, the southwesternmost contact of the basement with the Tulum Valley displays a topographic step between the 'Pampean peneplain' and the valley bottom that might record locally some vertical displacement along the SW Pie de Palo Anticline. Although, this sharper topography might also result from the fluvial erosion of the Precambrian basement by former meanders of the San Juan River, it is located on the possible northern termination of the Tulum fault system (Zambrano \& Suvires, 2008) (Fig. 2). This fault system, which is not accurately delineated and limits the western edge of the Pampean Precambrian outcrops from the Palaeozoic outcrops of the Eastern Precordillera (Ramos, Cristallini \& Pérez, 2002), corresponds further south, at Cerro Salinas, to the emerging ramp of the active Pampean thrust system (Vergés et al. 2007) (Fig. 2).

The structure controlling the Pie de Palo range, which strikes $\mathrm{N} 21^{\circ} \mathrm{E}$ and extends over $65 \mathrm{~km}$, is the most debated as it has been described as dipping $\mathrm{E}$ (Langer \& Bollinger, 1988; Costa et al. 2000; Ramos, Cristallini \& Pérez, 2002) or W (Kadinsky-Cade \& Reilinger, 1985; Reilinger \& Kadinsky-Cade, 1985). It is noteworthy that, in some interpretations, the E-dipping structure beneath Pie de Palo might root at depth on a W-dipping thrust (Ramos, Cristallini \& Pérez, 2002) and, in some others, the W-dipping structure branches at depth on an E-dipping thrust (Siame et al. 2015). The E-dipping hypothesis is based on the epicentre location of the $1977 M_{\mathrm{w}} 7.4$ earthquake within the southern Bermejo Valley, on the observation of Wverging faults affecting the Neogene deposits along the eastern edge of the Sierra Pie de Palo (Ramos, Cristallini \& Pérez, 2002), and on the fact that both the Eastern Precordillera and the westernmost Sierras Pampeanas form a W-verging thrust system. This fault would thus ramp off from the Valle Fértil - La Huerta Fault at a depth of $\sim 30 \mathrm{~km}$. In contrast, the Wdipping hypothesis is mainly based on levelling data after the 1977 earthquake showing an uplift of the southern Pie de Palo anticline (Kadinsky-Cade \& Reilinger, 1985) and crustal reconstructions from shallow and deep seismic profiling (Zapata, 1998) which favours a W-dipping, E-verging blind fault below the eastern border of the range. This hypothesis is also in good agreement with the observed first-order topographic signature of a steeper eastern flank, with higher Neogene dips along the eastern flank than the western one, and with a higher number of alluvial fans with steeper top surfaces than those that skirt over the western edge (Siame et al. 2015). An intermediate model displays both vergences: in the upper part of the crust the Sierra Pie de Palo is controlled by an E-verging structure that branches at depth on a W-verging one (Siame et al. 2002, 2005, 2015). Moreover, even in the $\mathrm{W}$-verging models, E-verging basement thrusts are also proposed below Pie de Palo (footwall thrust in Vergés et al. 2007).

Finally, a temporary seismic network, installed some ten years after the 1977 earthquake, allowed a much more accurate image of the microseismicity to be obtained (Regnier et al. 1992) that demonstrated the teleseismic locations are systematically mislocated with an eastward shift of c. $30 \mathrm{~km}$. Accounting for this shift, the 1977 epicentre should be moved c. $30 \mathrm{~km}$ westward, locating the 1977 focus below the southern Pie de Palo range (see discussion). These data also show that the northern part of Pie de Palo stands above aligned seismic foci that define on a cross-section a W-dipping fault (Fig. 4a), which ramps off from a $\sim 30 \mathrm{~km}$ depth and can be traced upward to a $7 \mathrm{~km}$ depth (Regnier et al. 1992). The foci depth distribution in the southern part of Pie de Palo provides a less clear image than the northern one; this vertical foci distribution might correspond to a pop-up structure (Fig. 4b; see discussion). In summary, the Pie de Palo anticline has been interpreted either as a fault-bend fold (W-verging structure), a fault propagation fold (E-verging structure), or a structure due to the interaction between both E- and W-verging structures. Focusing on puzzling Wverging reverse faults cropping out along the eastern edge and their mechanisms of deformation can help us to distinguish between these models and discuss how metamorphic basement is deformed under shallow conditions. Hereafter, we present new structural analyses, cross-sections and thin sections, allowing discussion of the structural evolution of the Sierra Pie de Palo at various scales.

\section{Structural analysis of the eastern Pie de Palo}

One of the most peculiar features of the eastern side of the Pie de Palo range corresponds to several occurrences of range-facing, $\sim \mathrm{N}-\mathrm{S}$-striking escarpments (Figs 3c, 5 and 6). These escarpments result from the Neogene to Quaternary activity of W-verging reverse faults that are parallel to the toe of the topography at several places. These faults are quite puzzling because their vergence apparently disagrees with the present topography as their relative vertical movement uplifts the South Bermejo Valley with respect to the Sierra Pie de Palo. These faults have been interpreted as the discontinuous surface trace of a major E-dipping, reverse fault, which would ramp off from a deep décollement related to the western border fault of the Valle Fértil - La Huerta range (Ramos \& Vujovich, 2000; Ramos, Cristallini \& Pérez, 2002). To better understand the meaning of these faults, we mainly focus our observations in two areas: Niquizanga (Fig. 5) and Ampacama (Fig. 6).

\section{4.a. The Niquizanga area}

In this area, two $\sim 5 \mathrm{~km}$ long, basement ridges are observed (Figs 5, 7a): the western Niquizanga and the eastern La Posta ridges. These two ridges are asymmetric, with a western steep slope bordered on the west by reverse faults while their eastern slope corresponds to the Neogene unconformity. At both ridges, the basement overthrusts the Neogene sediments. These layers 

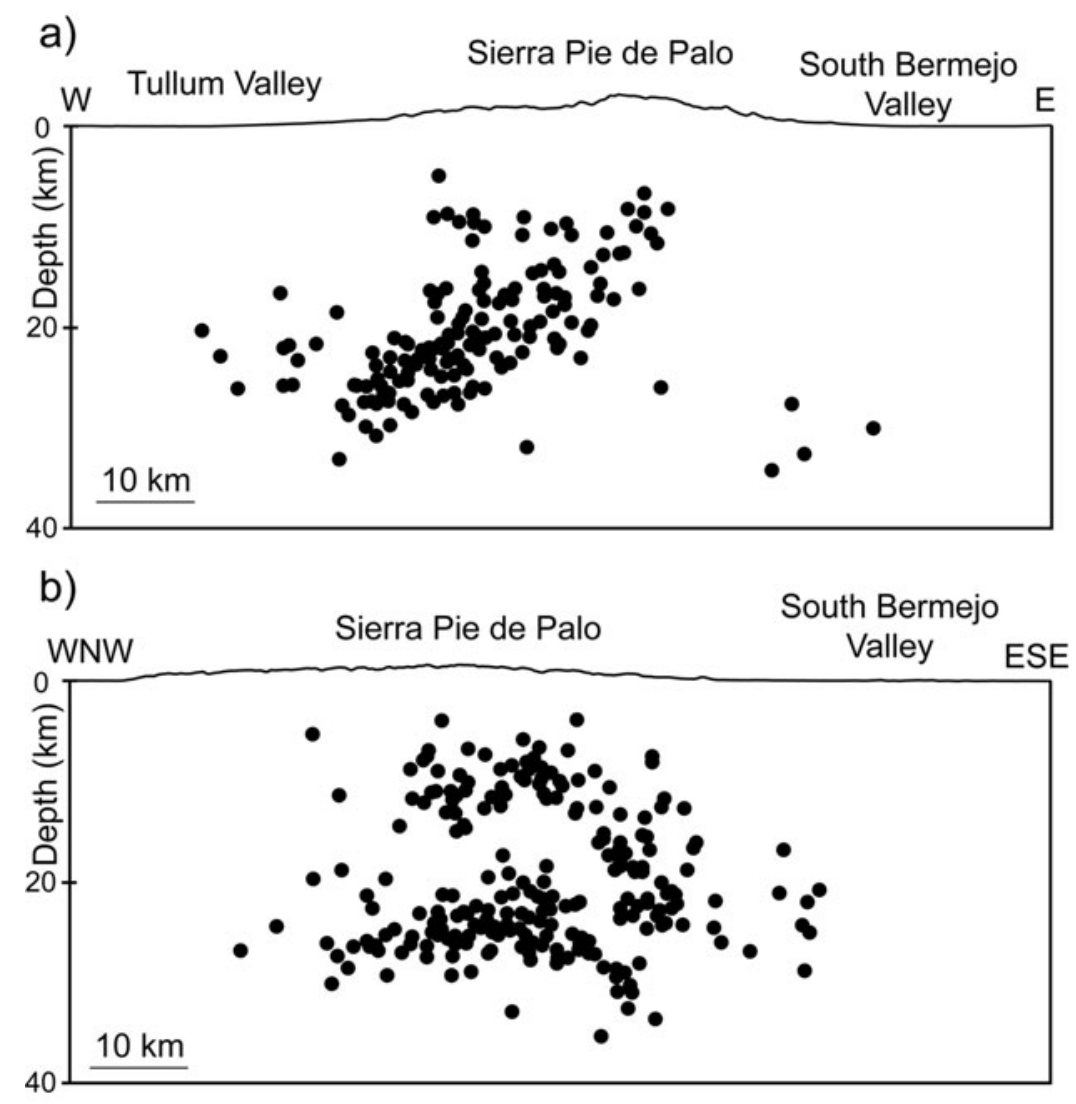

Figure 4. Seismicity profiles below the Sierra Pie de Palo showing seismic foci in vertical cross-sections redrawn after Regnier et al. (1992), (a) for the northern half of the sierra and (b) for the southern half of the sierra. See Regnier et al. (1992) for the original data and precise location of the earthquakes that were projected on the sections. See Figure 3 for location of the cross-sections.

present a syncline geometry in the footwall, with a shallow E-dipping limb (e.g. $07^{\circ} \mathrm{E}$ close to site 17; Fig. 5) and a steep to vertical W-dipping one (e.g. $90^{\circ}$ close to site 2; Fig. 5), attesting for W-verging kinematics for the fault. These faults are at least $6 \mathrm{~km}$ long and cannot be extended along more than $10 \mathrm{~km}$. Based on their $\sim 200 \mathrm{~m}$ high escarpment and the $10^{\circ} \mathrm{E}$ dip of the erosion surface below the Neogene sediments, the maximum fault displacement can be estimated to up to $500 \mathrm{~m}$. This Niquizanga bounding fault reactivated an inherited pre-Andean shear zone (Niquizanga shear zone) that was active as an extensional structure during the Silurian (Mulcahy et al. 2011).

In the basement, small faults, located in the hangingwall of the main $\mathrm{W}$-verging thrusts, are characterized by brittle deformation mainly parallel to the inherited metamorphic foliation. Microtectonic observations in the basement highlight an ENE-WSW contraction (sites 2, 6, 17, 23, 47; Fig. 5). This is consistent with the microtectonic observations in the sediments (ENE-WSW to ESE-WNW contraction, site 32; Fig. 5). Thus, it is most likely that the microfaults observed in the basement have the same age as the deformation seen in the late Tertiary - Quaternary sediments. Moreover, the shortening described above is also consistent with the overall N-S to NNE-SSW strike of the Pie de Palo anticline (Fig. 5), which is a late Tertiary-Quaternary feature. This also suggests that the brittle deformation observed in the basement is late Tertiary - Quaternary in age.

In addition, small-scale folds affecting both the sediments (site 32; Fig. 5) and the metamorphic foliation (sites 2, 6, 23; Fig. 5) are oriented NNW-SSE to N-S. These data also strongly suggest that all the mentioned deformation (both in the basement and the Cenozoic strata) is Plio-Quaternary in age and consistent with an overall $\mathrm{E}-\mathrm{W}$ shortening.

These folds and faults affecting the basement (Fig. 8) generally present $\mathrm{W}$-verging kinematics consistent with the kinematics of the two main faults. Moreover, the folds are brittle in the sense that their hinges are very localized and consist of few fractures while the limbs are very planar (Figs 8b, c, 9a). The folds also present kink geometries (Fig. 8a). These folds induce striations along the foliation planes (Fig. 9b), whose direction (roughly $\mathrm{E}-\mathrm{W}$ ) is also consistent with the $\mathrm{E}-\mathrm{W}$ shortening. Finally, in the basement, one may also observe larger folds (metric-scale or more; Fig. 9c). These folds and their wavelength imply strong disharmony and several levels of decoupling inside the basement.

Parallel to the metamorphic foliation, breccias are also very frequent. They consist of brecciated elements from the basement attesting for shearing, with little or no cement (Fig. 10a). The same feature can be observed with a higher amount of calcite cement (Fig. 10b, c). In thin section, one may clearly identify the 


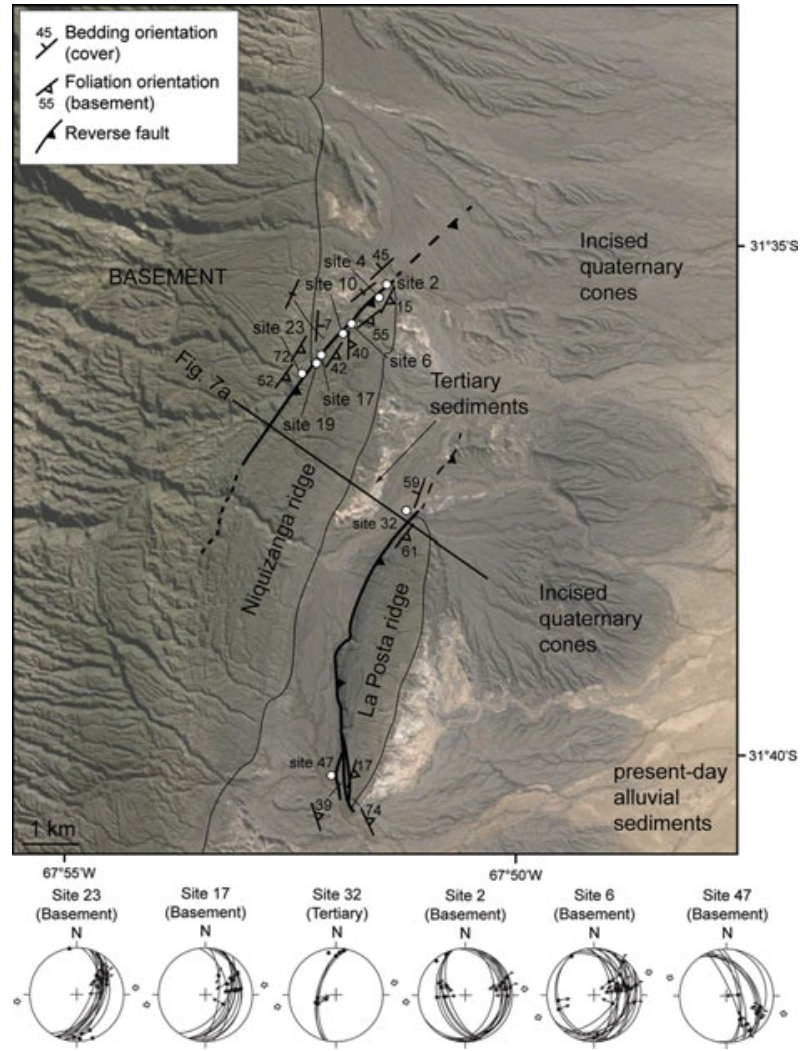

Figure 5. (Colour online) Structural data at Niquizanga. See Figure 3 for location. This area consists mainly of two basement ridges due to $\mathrm{W}$-verging thrust faults affecting both the basement and the Cenozoic sedimentary cover. The faults are NNE-SSW and attest for an ENE-WSW shortening according to the microtectonic data. The kinematic data show axes of deformation in the basement consistent with those in the cover. Fold axes (black dots in the stereonets) are also consistent with an ENE-WSW shortening, both in the basement and the cover. In the investigated sites (white circles with numbers), the basement foliation dips eastward.

original metamorphic rocks and newly formed calcite (Fig. 11c, d).

Brecciation, shearing, and small-scale folding seem strongly controlled by the anisotropy of the basement. Indeed, these structures are linked to levels of decoupling/décollement characterized by mica-rich layers (Fig. 11a) where brittle folds are rooting. Moreover, faults such as the La Posta Fault (Fig. 5) are clearly controlled by the inherited basement foliation: at its southern end, the fault turns systematically parallel to the inherited foliation. At larger scale, the La Posta fault also follows the inherited foliation: in the northern part, both the fault and the foliation are striking NNE-SSW; in the southern part, both the fault and the foliation are $\mathrm{N}-\mathrm{S}$.

On the eastern side of the section, the Neogene sediments (Fig. 7a) are gently dipping $\sim 5-10^{\circ}$ E. A $720 \mathrm{~m}$ thick Neogene series has been described in the Niquizanga area (Cuerda, Varela \& Iniguez, 1983), south of the La Posta Ridge (Fig. 5). Accounting for the map width of these Neogene sediments and their average dip just to the north of the Niquizanga ridge, we calculated a rough estimate of 600-700 $\mathrm{m}$ for the total Neogene

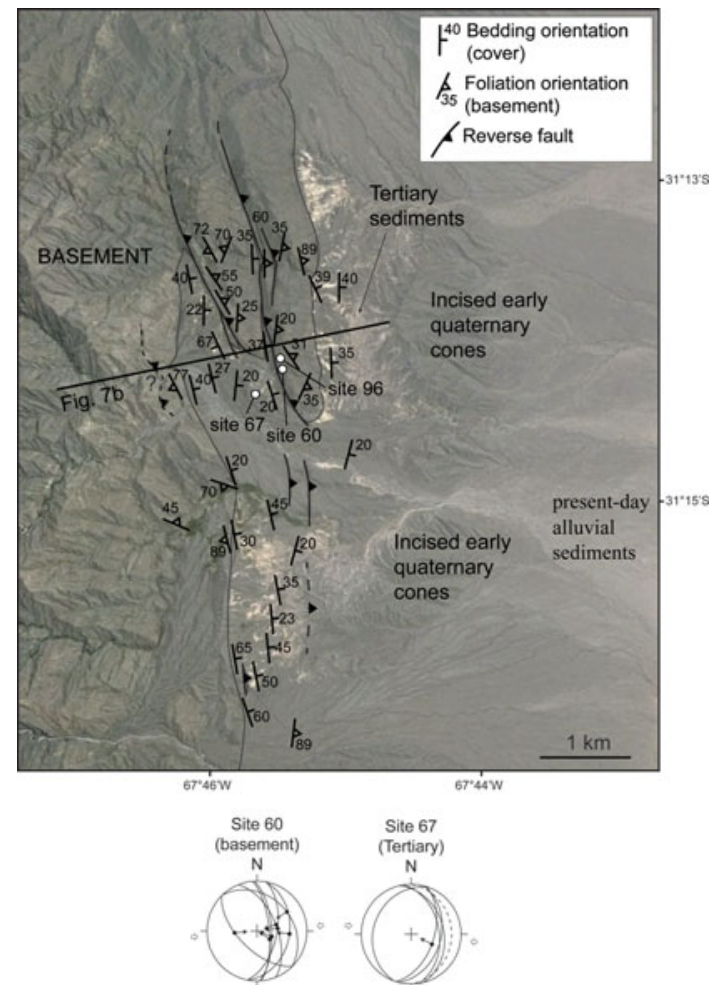

Figure 6. (Colour online) Structural data at Ampacama. See Figure 3 for location. This area consists of two main basement ridges due to $\mathrm{W}$-verging thrust faults in the basement, thrusting above the Cenozoic sediments. The faults are NNW-SSE and attest for an E-W shortening according to the microtectonic data. The kinematic data show axes of deformation in the basement consistent with those in the cover. In the investigated sites (white circles with numbers), the basement foliation usually dips eastward, although in several places it is either vertical or west-dipping.

thickness including the torrential conglomerates that are conformably topping the Neogene strata. This estimate is similar to the thickness calculated by Cuerda, Varela \& Iniguez (1983), indicating that the Neogene and basement brittle deformation, which are observed in the Niquizanga area, were formed at less than $1 \mathrm{~km}$ depth. Finally, no tapering structures or progressive unconformity were observed within the Neogene series. Nevertheless, the Late Neogene, Río del Camperito Formation (Cuerda, Varela \& Iniguez, 1983), which is coarser than the underlying Niquizanga Formation (see Section 3), contains metamorphic clasts from the Sierra Pie de Palo basement. These clasts indicate that these coarser Late Neogene sediments are coeval with the onset of the basement uplift.

\section{4.b. The Ampacama section}

If this area is comparable to Niquizanga in the sense that it displays several W-verging reverse faults (Fig. 6), Neogene beds have steeper dips and the basement ridges are more numerous in the Ampacama area. Indeed, we mapped seven faults: four in the northern part affecting the basement and the Neogene deposits; 
a) Niquizanga cross-section
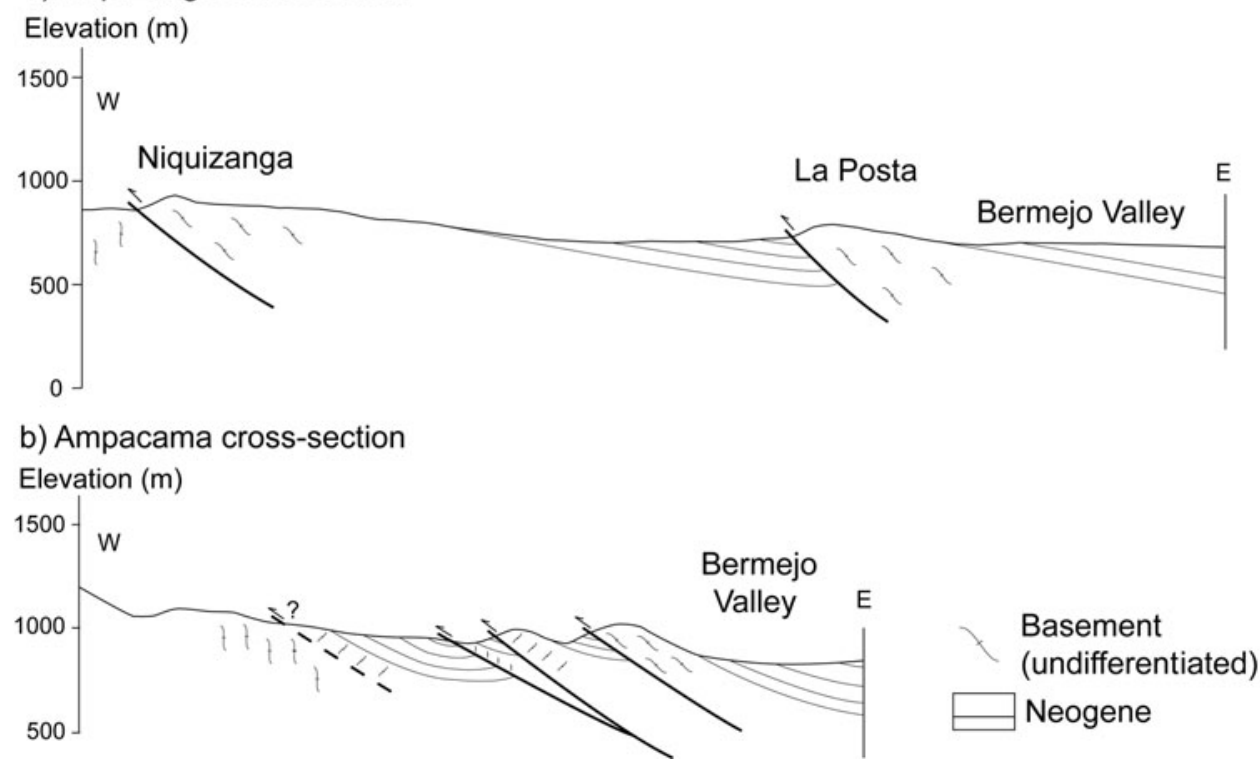

Figure 7. Cross-sections through both investigated areas. See Figures 5 and 6 for location. (a) Cross-section through Niquizanga area. Two faults are mapped and dip about $40^{\circ} \mathrm{E}$, with Neogene sediments between them. The faults are parallel to the inherited foliation in the basement. (b) Cross-section through Ampacama area. Three main thrusts are represented with dips about $30^{\circ} \mathrm{E}$. Along one of the faults, the fault plane is parallel to the basement foliation, while elsewhere it is strongly oblique. Between the basement thrust, the Neogene sediments mainly dip about $30^{\circ} \mathrm{E}$. A fourth fault is suspected in the western part, but no Tertiary sediments crop out to confirm it.

two in the sedimentary cover affecting both Neogene beds and Quaternary alluvial strath terraces; and one in the southern part affecting the basement and the Neogene. These faults are NNW-SSE to N-S and dip at about $40^{\circ} \mathrm{E}$ (Fig. $7 \mathrm{~b}$ ) and even $76^{\circ} \mathrm{E}$ for the southernmost one. The faults observed in the sedimentary cover may affect the basement at depth. Although this cannot be observed, it is suggested because these faults stand in the southward prolongation of the easternmost basement ridge. Most of these faults are at least $3-4 \mathrm{~km}$ long and have displacement up to $500 \mathrm{~m}$.

The faults in both the basement and the cover witness an E-W shortening (Fig. 6), which is consistent with the microfaults reported for the southern Niquizanga area (Fig. 5).

In this area, it is noteworthy that several basement faults are parallel to the inherited metamorphic foliation, while some others are strongly oblique, or even perpendicular (Fig. 7b). Where the faults are oblique to the foliation, the latter is not characterized by a strong mineralogical segregation, i.e. the foliation is particularly not underlined by mica-rich layers (Fig. 11b).

The sedimentary layers are folded in this area, mainly as synclines between the basement ridges. Along their western limb, the dips are about $20-40^{\circ} \mathrm{E}$, while in the eastern limb they can be up to $60-70^{\circ} \mathrm{W}$. These geometries attest for significant asymmetries, which are also consistent with the $\mathrm{W}$-verging basement thrusts.

Further west, in the Pie de Palo range, recent basement fault zones are also suspected (westernmost fault with a question mark; Figs 6, 7b). These faults are characterized by intensively fractured and faulted rocks, with a clear W-verging kinematics. However, due to the lack of Neogene sediments, their age cannot be strictly constrained. It is noteworthy that, in this area in particular as well as a few others, the basement foliation is not E-dipping, but is rather vertical to W-dipping. Further south, the foliation is also clearly folded: indeed, the orientation changes a lot in a rather restricted area (Fig. 6).

In the southernmost part of Ampacama, the sedimentary layers have dips increasing westward (from 20 to $65^{\circ}$ and even vertical in a few places; Fig. 6 , southern part). In the area where the Neogene layers are steeper $\left(50-62^{\circ} \mathrm{E}\right)$, a sub-vertical basement slice $\left(89^{\circ} \mathrm{E}\right)$ crops out. On its western side, a very steep $\left(62^{\circ} \mathrm{E}\right) \mathrm{W}$-verging fault can be observed at the contact with the Neogene (Fig. 6). In this area, where the Neogene beds show steeper dips than in the southern Niquizanga area, the basement reverse faults affecting the Neogene also tend to be steeper.

As in the Niquizanga area, the Neogene series is composed of two sedimentary formations that are conformably capped by Early Quaternary alluvial conglomerates (Fig. 6). No detailed study is available on this Neogene series. Using the same kind of method as in the Niquizanga, we calculated two rough estimates for the Neogene maximum thickness: a first one of $\sim 900 \mathrm{~m}$ to the east of the eastern basement ridge and a second one of $\sim 1100 \mathrm{~m}$ on the southern part of the Neogene outcrop. These two estimates suggest that the thickness of the Ampacama Neogene series is on the order of $1000 \mathrm{~m}$, hence slightly thicker than the Niquizanga Neogene formations. Nonetheless, the Ampacama thickness estimates also indicate that the Neogene 
a)

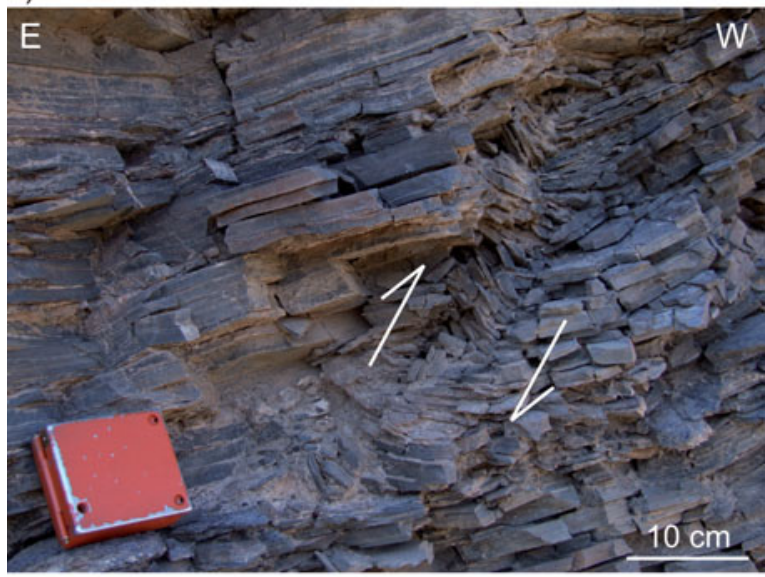

b)

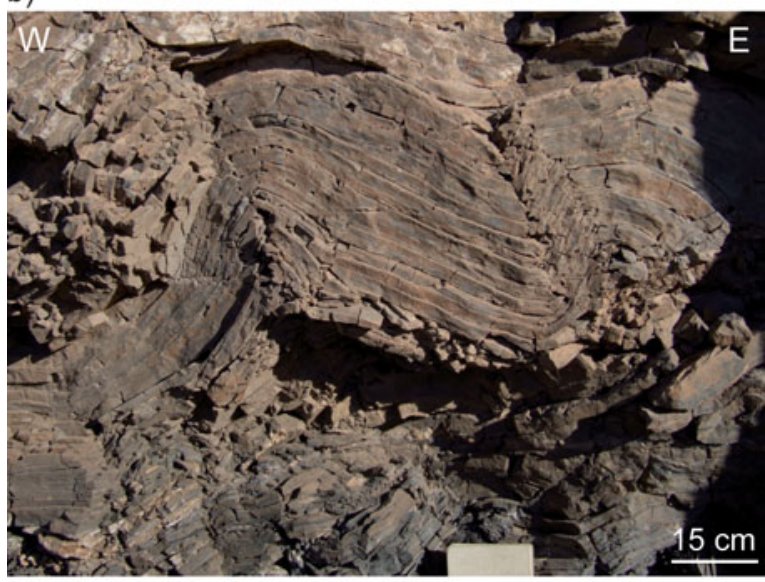

c)

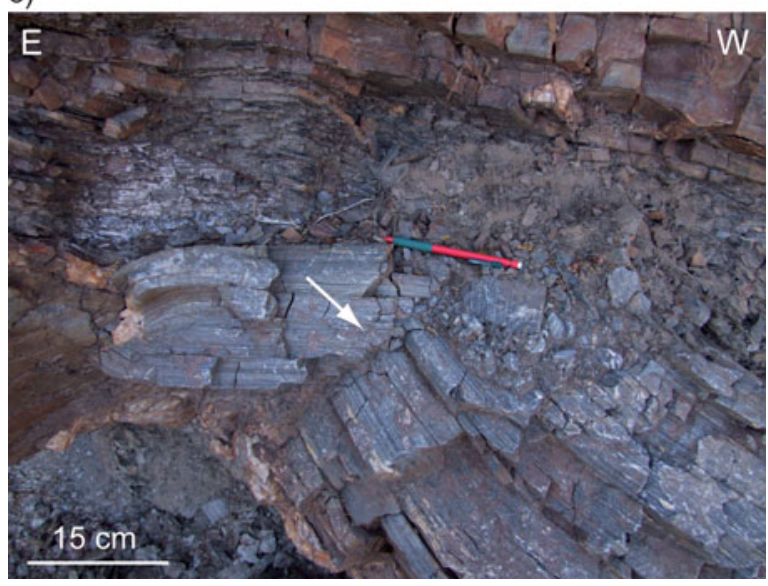

Figure 8. (Colour online) Field photographs of folds affecting the basement rocks. The folds display very brittle style with (a) kink geometries (site 2, Fig. 5), and (b, (c) sharp, fractured hinges with planar limbs (sites 10 and 17, respectively, Fig. 5), while the inherited ductile deformation can still be observed as boudins (c). Note that the fold axes are approximately N-S and that preferential vergence of the folds is systematically a $\mathrm{W}$-vergence.

deformation seen within the basement was formed under very shallow depth conditions. As in Niquizanga, the Neogene layers are characterized by lower dips on the eastern side of the section $\left(20-35^{\circ} \mathrm{E}\right)$ while they show steeper $\left(40-65^{\circ} \mathrm{E}\right)$ dips in the western part (Fig. 7a). No progressive unconformities or sediment- ary tapering were observed in the field. Nevertheless, as in Niquizanga, the Upper Neogene Rio del Camperito Formation is coarser and contains clasts of metamorphic rocks derived from the Sierra Pie de Palo. This indicates that the basement of the Pie de Palo range was actively uplifting and under erosion during the Upper Neogene.

\section{4.c. Synthesis}

To sum up, here are our main observations. At two locations, small (in both length and displacement) W-verging reverse faults are mapped east of the Sierra Pie de Palo: these faults have lengths ranging between 2 and $6-7 \mathrm{~km}$ but can hardly reach $10 \mathrm{~km}$; their displacements are usually less than $c .500 \mathrm{~m}$. Compared to the length of the Pie de Palo Range, these faults are typically second-order structures. Most of these faults reactivated the inherited metamorphic foliation and/or shear zones, especially along mica-rich levels with an oriented fabric (Fig. 11a). Along these planes, close to and above the reverse faults, we observed foliationparallel slip, breccias and folded foliation planes in between. The kinematics of these structures is consistent with both the microfaults measured within the sediments and the faults showing basement over sediments, as well as the overall geometry of the Pie de Palo range. This kinematics is also similar to that obtained from the inversion of earthquake focal mechanisms (Siame et al. 2005). It is noteworthy that this top-to-the-west kinematics is most likely not inherited from pre-Andean times, as Palaeozoic top-to-the-east kinematics and associated lineations were observed in the Niquizanga shear zone. Thus, the reverse, top-tothe-west movement is most probably Neogene.

These $\mathrm{W}$-verging faults have displacement ranging between a couple of hundred metres and $500 \mathrm{~m}$. In some places (Fig. 6, southern part), the upward fault propagation is accompanied by gentle folds within the Neogene. Displacements in the Quaternary strath terraces are always much lower than within the Neogene formations. The northward prolongation of the Niquizanga basement ridge is at the limit of identification within the Quaternary alluvial surface. On the other hand, the surface of the Quaternary alluvial does not appear affected by the northward prolongation of the La Posta Ridge, while the underlying Neogene is still tilted (Fig. 5). In the Ampacama area, where the Neogene beds are more deformed, a tier of Middle to Late Quaternary strath terraces is conspicuously gently folded, the highest, hence oldest, surface terrace showing steeper dips than the younger ones. Nevertheless, the Quaternary terraces' displacements and dips are much smaller than those observed within the Neogene. All these data provide clear evidence that these $\mathrm{W}$-vergent reverse faults are typically early within the deformation timing of the Sierra Pie de Palo. Moreover, the fact that steeper fault dips are always associated with the steeper Neogene dips also strongly suggests that these 
a)

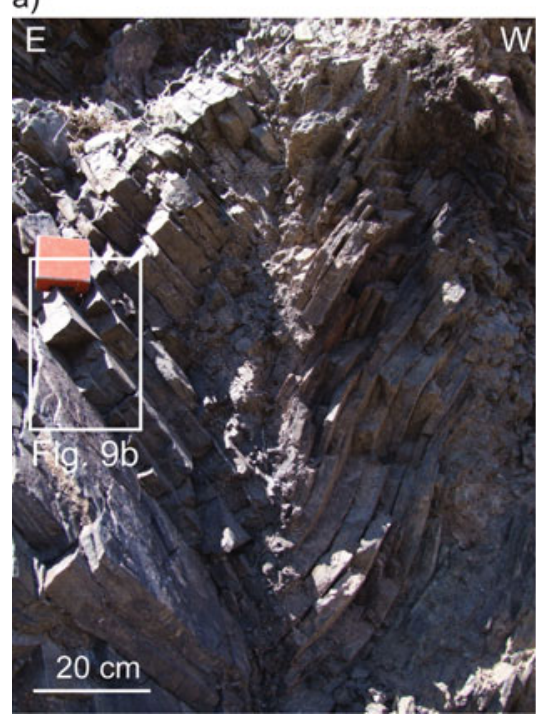

b)

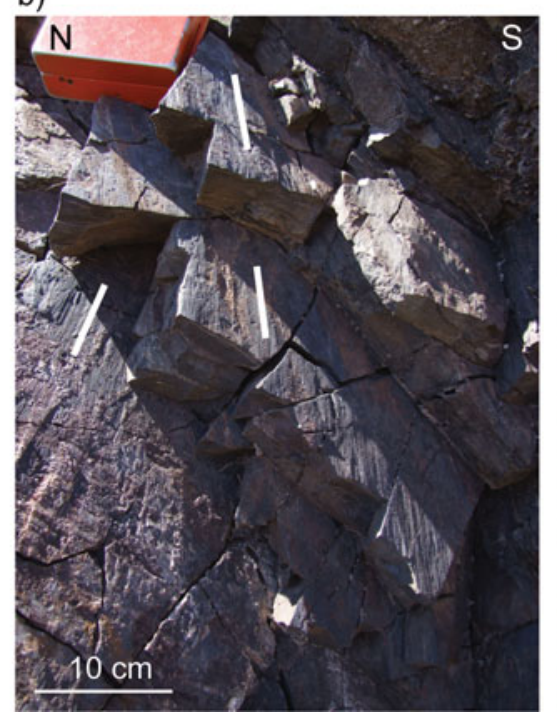

c)

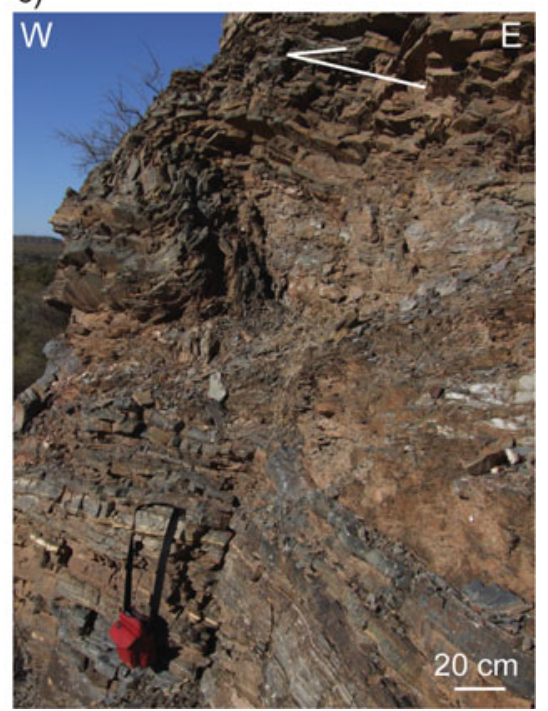

Figure 9. (Colour online) Field photographs of folds affecting the basement rocks. (a) Fold with sharp and fractured hinge and (b) associated foliation-parallel slip (site 2, Fig. 5). Fold and slip indicate an E-W shortening. (c) Larger-scale fold in the basement. Note the $\mathrm{W}$-verging kinematics.

second-order faults are early in the folding timing of the Sierra Pie de Palo

In between the two described areas, neither basement rocks nor reverse faults are clearly identified along the central-eastern side of the Sierra Pie de Palo. The only dubious candidate for such a faulted basement ridge could stand in the Casas Viejas area $\left(31.38^{\circ} \mathrm{S}, 67.81^{\circ} \mathrm{W}\right)$ (Fig. 3b). However, it is difficult in this area to distinguish between the Neogene beds and a highly hydrothermal-altered basement. Either such basement ridges are present, but buried below the Neogene beds, or they did not develop in the same way in the central part of the fold as in the areas of Niquizanga and Ampacama. It is worth mentioning that similar range-facing scarps, striking NW-SE, are also observed within Quaternary alluvial fans of the NE corner of the Pie de Palo range $\left(31.09^{\circ} \mathrm{S}, 67.8^{\circ} \mathrm{W}\right)$, $5-7 \mathrm{~km}$ to the SE of the Pajaritos fault (Figs 2, 3).

All these observations suggest that $\mathrm{E}-\mathrm{W}$ shortening was accommodated at the surface in several places by shear along foliation planes and inherited shear zones. In the next section, we detail how these newly created shear zones reactivating the foliation may evolve through time, how the Sierra Pie de Palo developed and what implications this has for the crustal structure.

\section{Mode of upper crustal shortening}

\section{5.a. Foliation-parallel shear}

We showed above that most of the small reverse faults observed along the eastern side of the Sierra Pie de Palo initiated as foliation-parallel shear zone, controlled by (i) the inherited anisotropy of the foliation and (ii) the presence of low-strength mineral phases such as micas.

Micas are weak mineral phases, and few experimental works have underlined that mica-rich aggreg- ates are weaker than other rocks (such as quartzofeldspathic ones) over a broad range of mid-crustal depths (Shea \& Kronenberg, 1992). Although the deformation at Sierra Pie de Palo occurred at much shallower depth than mid-crust, we may assume that the micas also behave as weak phases at shallow depths. In this case, they would allow accommodation of a large amount of strain, hence localizing the deformation and constituting shear zones.

Probably more significant than the intrinsic mechanical properties of these mineral phases, their anisotropy has been shown to control the rock strength. Indeed, in rock mechanics experiments, the weakening is controlled by the orientation of micas relative to the stress orientation (Shea \& Kronenberg, 1993). This means that the softening is controlled by both the presence of micas (or any other phyllosilicate) and, more importantly, their arrangement (e.g. Bos \& Spiers, 2001, 2002; Niemeijer \& Spiers, 2005; Jefferies et al. 2006; Collettini et al. 2009; Niemeijer, Marone \& Elsworth, 2010; Holdsworth et al. 2011).

Hereafter, we propose a field-based conceptual model for the evolution of mica-rich foliated basement rocks deformed at low depths (Fig. 12). Initially, the foliation has overall a shallow dip (i.e. before Late Neogene folding), then it is activated as reverse shear zones (Fig. 12b) on weak mica layers. At small scale, these weak layers act as local décollement, and thin quartzofeldspathic layers start forming asymmetric folds consistent with the sense of shear (Fig. 12b). If deformation continues, the folded thin quartzo-feldspathic layers evolve as breccias subsequently more or less cemented by calcite (Fig. 12c). Ultimately, this zone can turn into a localized zone of shear. Thus, at larger scale, once this zone can accommodate significant deformation, it may act as a décollement level for larger folds involving a thicker pile of metamorphic rocks (Figs 9c, 12d). This 
model accounts for the discrete shear zones/faults, large as well as small folds observed in the field.

This model assumes that the deformation seen in the hangingwall of the main reverse faults can be interpreted as 'immature' structures that formed the reverse faults. Thus, foliation-parallel slip was localized along the main reverse faults as well as distributed in their hangingwall (and footwall?). Additionally, some reverse faults are simply the reactivation of inherited shear zones (see above, Niquizanga thrust). The reactivation of other inherited Pampean thrusts/shear zones was already suggested from seismic line interpretation in the W-verging model (Vergés et al. 2007).

As mentioned in Section 4, these structures formed at very shallow depth, i.e. c. $1 \mathrm{~km}$, based on the estimated thickness of the Neogene sediments around Sierra Pie de Palo. This explains why only very brittle structures are observed, such as very localized shear zones, faults, brittle folds with very localized and fractured hinges, planar limbs, and breccias (Figs 8-10).

At such shallow depth, the basement rocks are usually deformed in a very localized mode, i.e. with large faults or a series of smaller ones (e.g. Scholz, 2002; Handy, Hirth \& Hovius, 2007). For the Pie de Palo Range, along with the small thrusts mapped in the field, the main feature is the anticline shape of this range, especially highlighted by relicts of the pre-Neogene erosional surface (Siame et al. 2015). In the next section, we discuss the mode and kinematics of such a basement shortening.

\section{5.b. Fault vergence at the Sierra Pie de Palo}

The deformation of the eastern Sierra Pie de Palo consists of several W-verging reverse faults. These faults, which have small lengths $(2-8 \mathrm{~km})$ and small displacements (less than 0.2 to $0.5 \mathrm{~km}$ ), are narrowly spaced $(0.5-3 \mathrm{~km})$ and correspond mostly to foliation-parallel, brittle shear zones that start developing within weak foliation levels of the basement during the early stage of folding. Consequently, their significance needs to be discussed in the framework of the folding models which have been proposed for the Pie de Palo anticline, i.e. W-verging fault-bend fold (Ramos, Cristallini \& Pérez, 2002; Vergés et al. 2007) or E-verging faultpropagation fold whose blind thrust branches at depth on a W-verging thrust (Siame et al. 2002; Siame, Bellier \& Sebrier, 2006) or not (Kadinski-Cade and Reilinger, 1985), especially in terms of the mechanism that distributes deformation in the basement.

According to Ramos, Cristallini \& Pérez (2002), the W-verging Niquizanga Fault (at Niquizanga Ridge; Figs 5, 7), which is located at the rear of the Pie de Palo fault-bend fold, is a rather steep reverse fault ramping off below the eastern South Bermejo Basin, at more than $20 \mathrm{~km}$ depth. Such a fault contradicts the longterm topography (the southern Bermejo Valley should be uplifted and the Sierra Pie de Palo should be subsiding) and could only fit with an out-of-sequence structure. However, this option disagrees with our observa- a)

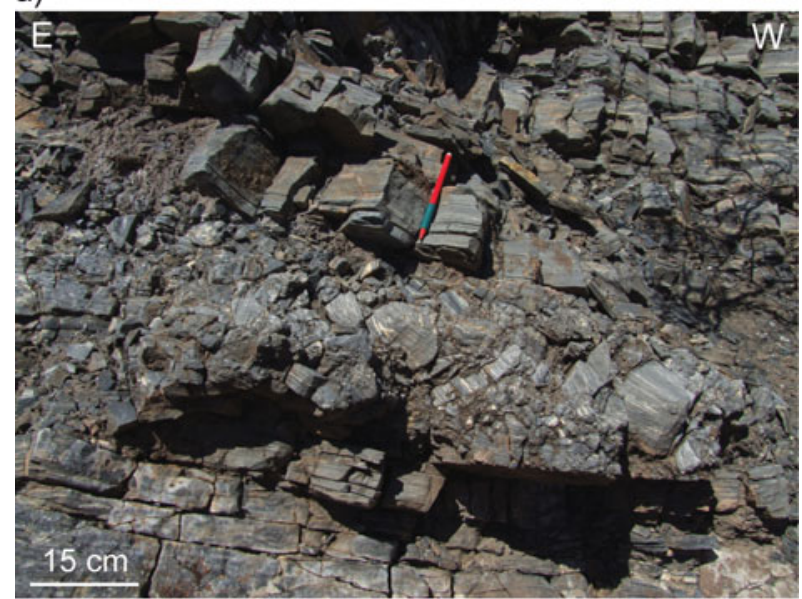

b)

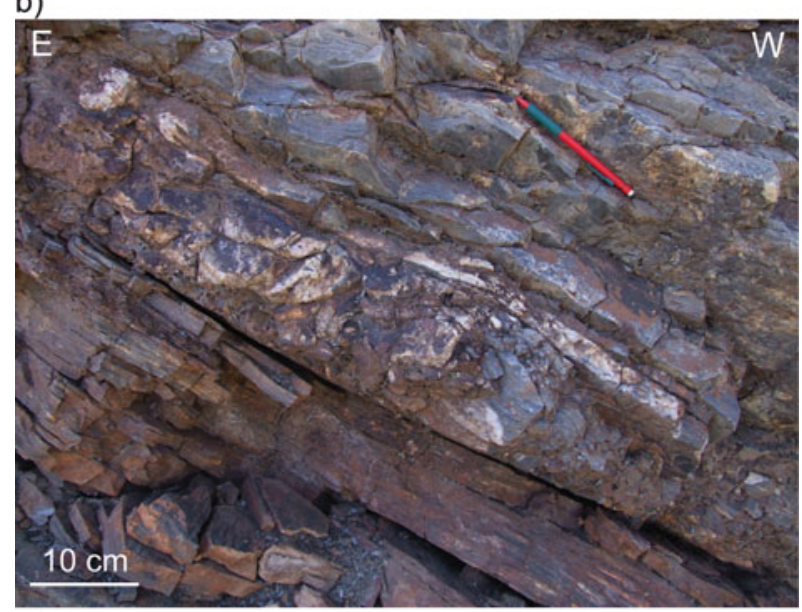

c)

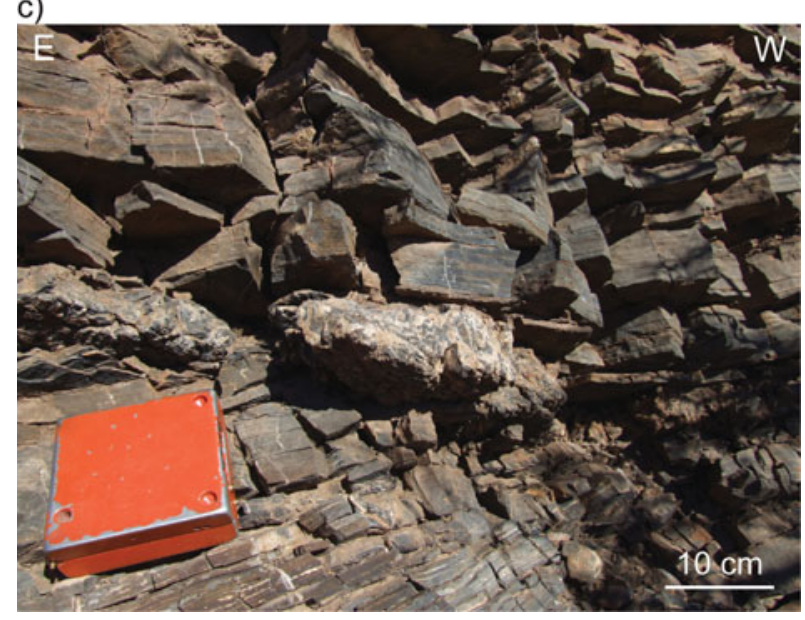

Figure 10. (Colour online) Foliation-parallel breccias. (a) With no cement (site 23, Fig. 5). (b, c) With more cement (site 10, Fig. 5).

tions because the $\mathrm{W}$-verging faults have short lengths, appear tilted with the sedimentary bedding and can thus hardly ramp off at $20 \mathrm{~km}$. Moreover, their displacement pre-dates or more likely is coeval with the folding, hence partly early in the deformation timing of the Pie de Palo Anticline.

Another alternative associated with a fault-bend fold might correspond to what was proposed for the Alpine basement units in the Pyrenees Axial Zone (Casas et al. 
a)

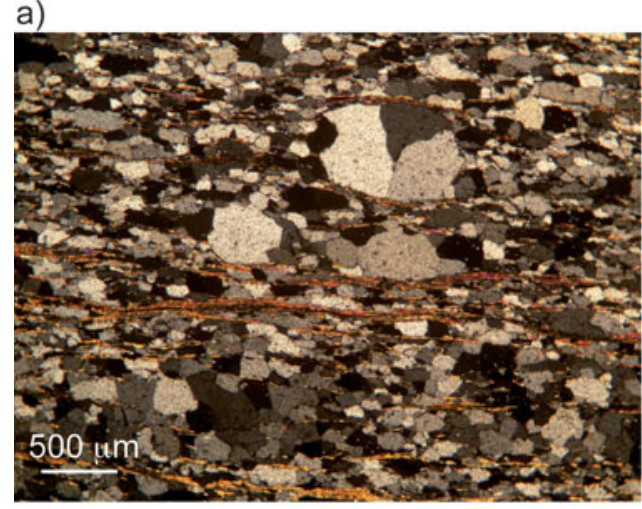

b)

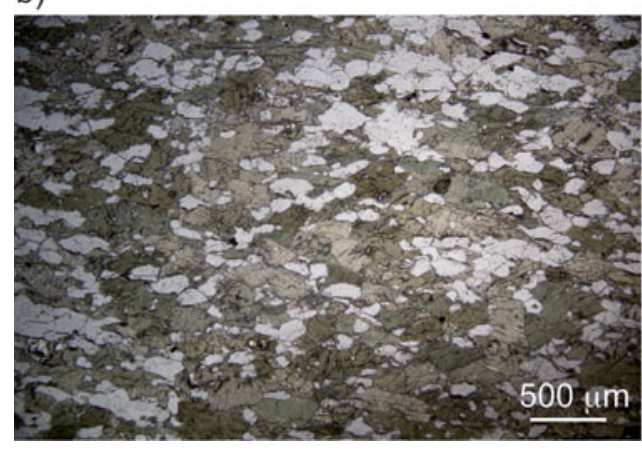

c)

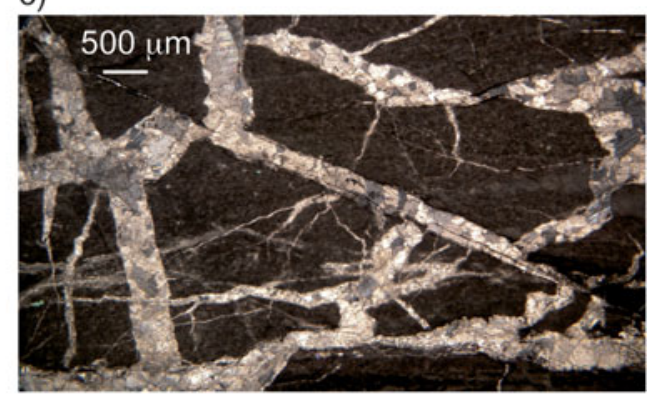

d)

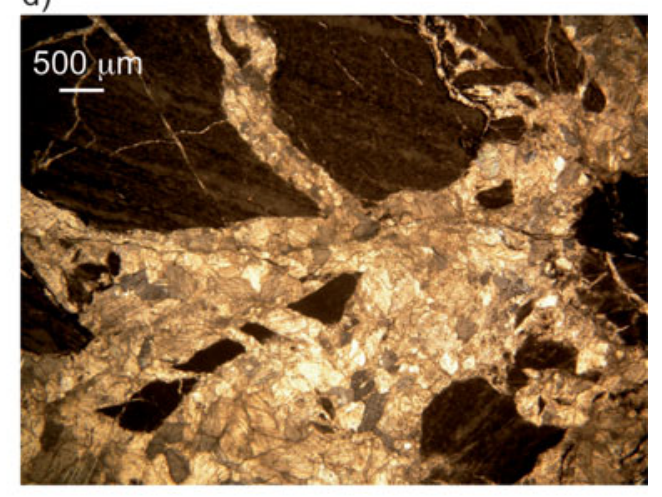

Figure 11. (Colour online) Microphotographs. (a) Micaschist (site 4, Fig. 5) with foliation underlined by quartz and micas. (b) Quartzofeldspathic rocks with a high amount of chlorite and no clear anisotropy (site 96, Fig. 6). (c, d) Breccias and calcitic cement in the brecciated layers (site 23, Fig. 5).

2003). There, steep Meso-Cenozoic faults affect both the basement and its Mezosoic cover. They are interpreted as faults initiated in the basement where it passed above a flat-ramp-flat system. Indeed, in such a case, the structural configuration and kinematics implies internal deformation within the basement (Casas et al. 2003). Such a model could be contemplated for the Pie de Palo anticline assuming a fault-bend fold (Ramos, Cristallini \& Pérez, 2002; Vergés et al. 2007). Where the basement passes above a flat-ramp or a ramp-flat transition, there might be either contraction or extension in the upper unit, respectively. The W-verging reverse faults observed in the field might then witness this later configuration. However, this would imply that they formed at depth, as the flat-ramp transition is in the deep crust. This is unlikely given the brittle structures observed in the field.

Considering that these small W-verging faults are observed in the eastern part of the Pie de Palo anticline, which corresponds to a forelimb accounting for the shape of the erosional surface (Fig. 3), makes it necessary to test the E-verging fault propagation fold model. In such a model, the W-verging faults could represent intercutaneous structures such as have been observed at several places (e.g. Mackay et al. 1996). If so, the slip on an E-verging blind basement fault would be distributed on several W-verging small basement faults. However, one would expects such an intercutaneous wedge structure to develop rather late in the deformation timing. Thus, this option remains possible, but not very likely because our observations suggest these small $\mathrm{W}$-verging faults started to develop early in the sequence of shortening.

Considering that these small W-verging reverse faults are located in the forelimb of the Pie de Palo anticline, where the dips are steepest $\left(30-90^{\circ}\right)$, one can surmise that they are linked to a mechanism of folding. This fault pattern being due to foliation-parallel slip resembles the bedding-parallel slip in the flexural-slip fold model. The role of basement pre-existing fabric has been highlighted in several basement-cored folds (Schmidt, Genovese \& Chase, 1993). The mode of folding described above may belong to 'mode 2' of Schmidt, Genovese \& Chase (1993). However, in this latter work, the fabric allowed the deformation to be distributed in the basement in the sense that the zone of deformation below the forelimb is large. Nonetheless, the mode of deformation is not folding s.s. It rather corresponds to a distributed mode of faulting that induced a fold in the overlying sedimentary cover.

Such a zone of deformation in the basement has been described in a few places and often interpreted as a triangular shear zone, large toward the basement top, rooting and thinning downward in the upper tip of a thrust. Such a model has been generalized for the sedimentary rocks by Erslev (1991) as a trishear mode of folding and applied for the basement to explain distributed faulting below the basement/cover interface (Bump, 2003; Garcia \& Davis, 2004). If the fault upper tip is initially located in the basement, there might be, near the fault tip, a triangular zone of distributed deformation active until the fault potentially 
a) Initial inherited heterogeneity (foliation)

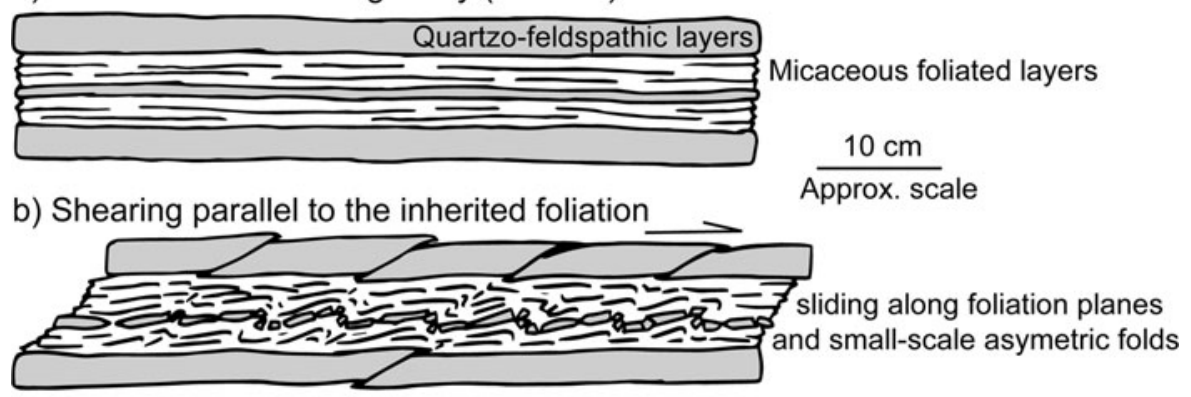

c) Shearing and breccias
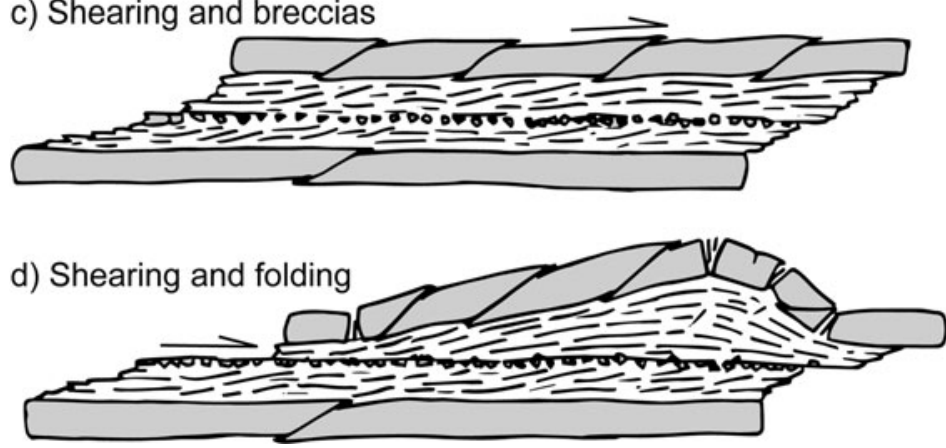

Figure 12. Conceptual model of shear zone development. (a) Inherited metamorphic foliation with both quartzo-feldspathic and mica-rich layers. (b) Shearing induces disharmony with folding of thin quartzo-feldspathic layers embedded between mica-rich layers that most likely accommodate foliation-parallel shear. Layer-parallel shortening of the upper quartzo-feldpsathic layer is represented for balancing purposes, although this has not been clearly observed in the field. (c) Breccias resulting from the breakdown of the folded quartzo-feldspathic layer. The shearing localizes in this brecciated zone. (d) Ultimately, this brecciated layer may evolve as a new local décollement allowing the development of larger folds affecting the upper quartzo-feldspathic layers.

propagates to the basement/cover interface. In this zone, the basement may deform by pervasive faults and fractures, either pre-existing or newly created (Garcia \& Davis, 2004); this induces a curved basement/cover interface because of distributed deformation. If such a model applies for Sierra Pie de Palo, an E-verging basement thrust should terminate upward with a distributed zone of shear characterized by W-verging small faults.

Such switch of vergence makes the trishear model unlikely for the Sierra Pie de Palo, although it cannot be ruled out. Thus, finally, the small W-verging faults more probably witness a foliation parallel-slip mode of folding associated with an E-verging fault-propagation fold, similar to what has been proposed for sedimentary rocks (Suppe $\&$ Medwedeff, 1990). Above the blind thrust tip, a fold developed to accommodate shortening. In this fold, the mode of folding, i.e. the way the distributed deformation is accommodated, is characterized by slip along inherited foliation planes (or inherited shear zones). Even if our observations cannot provide any kind of evidence to root a trishear model, one cannot totally discard it where the E-verging fault tip propagates at depth. In such a case it would coexist with the foliation-parallel slip model we propose for the Pie de Palo anticline.

Interestingly, unfolding the Neogene Pie de Palo anticline reveals a pre-existing series of antiforms and synforms (Fig. 13a) suggesting that the Neogene and Quaternary shortening should have amplified inherited basement antiformal geometries (Fig. 13b): in the west- ern part of the sierra, the inherited foliation appears folded, with dips much higher than the erosional surface (Figs 3, 7, 13). In the western Pie de Palo limb, several pre-Andean E-dipping thrusts are mapped and most of them are associated with E-dipping foliation (e.g. Mulcahy et al. 2011; Van Staal et al. 2011). However, W-dipping foliation can also be observed in some places (e.g. Mulcahy et al. 2011; Van Staal et al. 2011), especially at the sierra top (Ramos \& Vujovich, 2000). Thus, in the western limb, a series of antiforms and synforms of foliation is inherited, while at the sierra top and in the eastern limb a single asymmetric antiform is inherited from a pre-Andean event (Fig. 13). Thus, we propose that the foliation-parallel slip mechanism for folding is relevant and could be the main folding mechanism determining the present-day shape of the Pie de Palo anticline. In such a case, as mentioned above, this mechanism would somewhat resemble the flexural-slip model, hence, foliation-parallel slip in the basement would play the role of bedding-parallel slip in the cover. To accommodate the shortening in a flexural-slip fold, there is partitioning between bedding-parallel slip and layer internal deformation (fractures, veins, pressuresolution, twinning). In our model of the foliationparallel slip mode of folding, there is also a partitioning between slip along inherited foliation planes (reverse faults; Figs 7, 12,13) and internal deformation of basement rocks (here, fractures mainly; Figs 8 and 9). Such deformation is most likely similar to that observed in the field: 'brittle' folds with planar limbs and localized hinges (Figs 8 and 9). 
a) Sierra Pie de Palo, present day
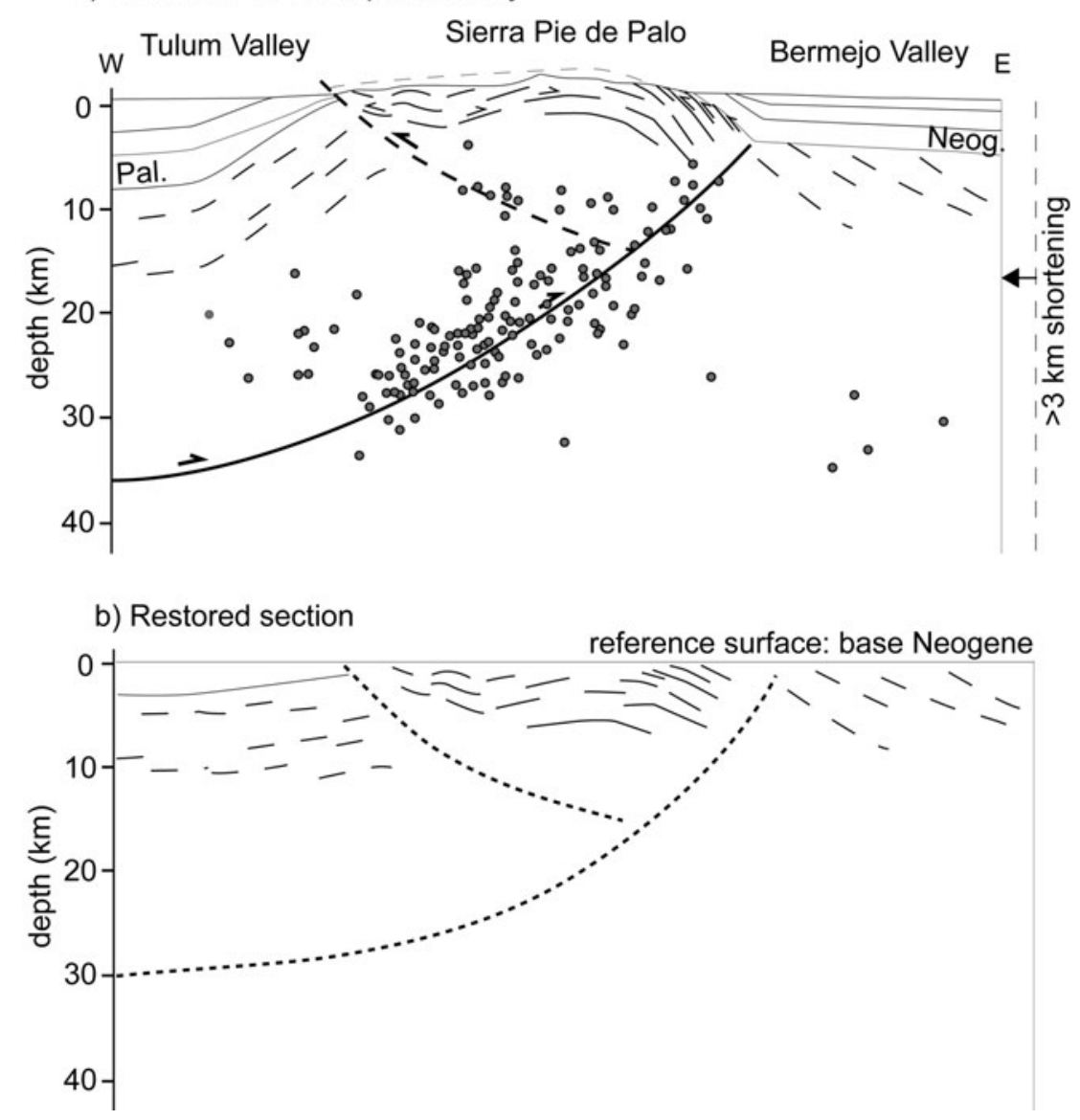

Figure 13. (a) Cross-section of the Pie de Palo (see Fig. 3 for location) and (b) its restoration. In (a) the foliation traces are from field observation and geological maps (see Fig. 3) for the surface ones. East of Pie de Palo, at depth, the inherited foliation is projected southward from seismic lines located NE of Pie de Palo (Zapata, 1998). Seismic foci in the northern part of the Pie de Palo (Regnier et al. 1992) were projected on the section (dots). Pal. for Palaeozoic; Neog. for Neogene.

It is noteworthy that the reverse faults interpreted as witnessing flexural-slip mechanism are spaced a few hundred metre to a couple of km apart (Figs 5,6). This fits well with the fact that the displacements along these faults are on the order of about a few hundred metres (Fig. 7), as predicted by Alonso (1989).

In some places where the foliation was previously intensively folded, at smaller scale than the basement antiform (see spatial variations of foliation orientation in Fig. 5), new faults were laterally propagated and created oblique to the local foliation, to ensure a kinematics consistent at fold scale.

Therefore, the $\mathrm{W}$-verging small reverse faults seen along the eastern side of the Pie de Palo anticline agree with an E-verging fault propagation fold. Moreover, the dip of the Neogene series in the eastern Pie de Palo is very high at some places (more than $60^{\circ}$; Fig. 6), which does not fit well with a fault-bend fold model where such dips should represent the dip of the Wverging thrust. Thus, although the $\mathrm{W}$-verging model cannot be totally discarded we have shown that structural data permit the suggestion of an alternative model with a major crustal blind thrust and an associated fault-propagation fold (Figs 13, 14). Moreover, this surmised major crustal blind thrust is quite consistent with local microseismic data (Regnier et al. 1992) showing a W-dipping alignment of foci (average dip around $30-35^{\circ} \mathrm{E}$ ), especially in the northern part of Pie de Palo (Figs 4a, 13, 14). Two mechanisms can fit with this latter structural model: intercutaneous faults or foliation-parallel slip mechanism, this second mechanism being much more likely. Finally, the Neogene Pie de Palo fold appears to have developed on inherited basement antiformal and synformal geometries.

\section{Crustal and lithospheric structure}

Our main results are twofold: first, we show how the inherited metamorphic foliation controlled and influenced the formation of small faults in the basement, and second, we argue that the overall kinematics of the Sierra Pie de Palo as well as the depth distribution of seismic foci are consistent with an E-verging faultpropagation crustal fold. In the following sections, we propose a more speculative discussion at both crustal and lithospheric scales.

\section{6.a. Crustal implications}

We have proposed that the dominant folding mechanism should be foliation-parallel slip and that it induced 

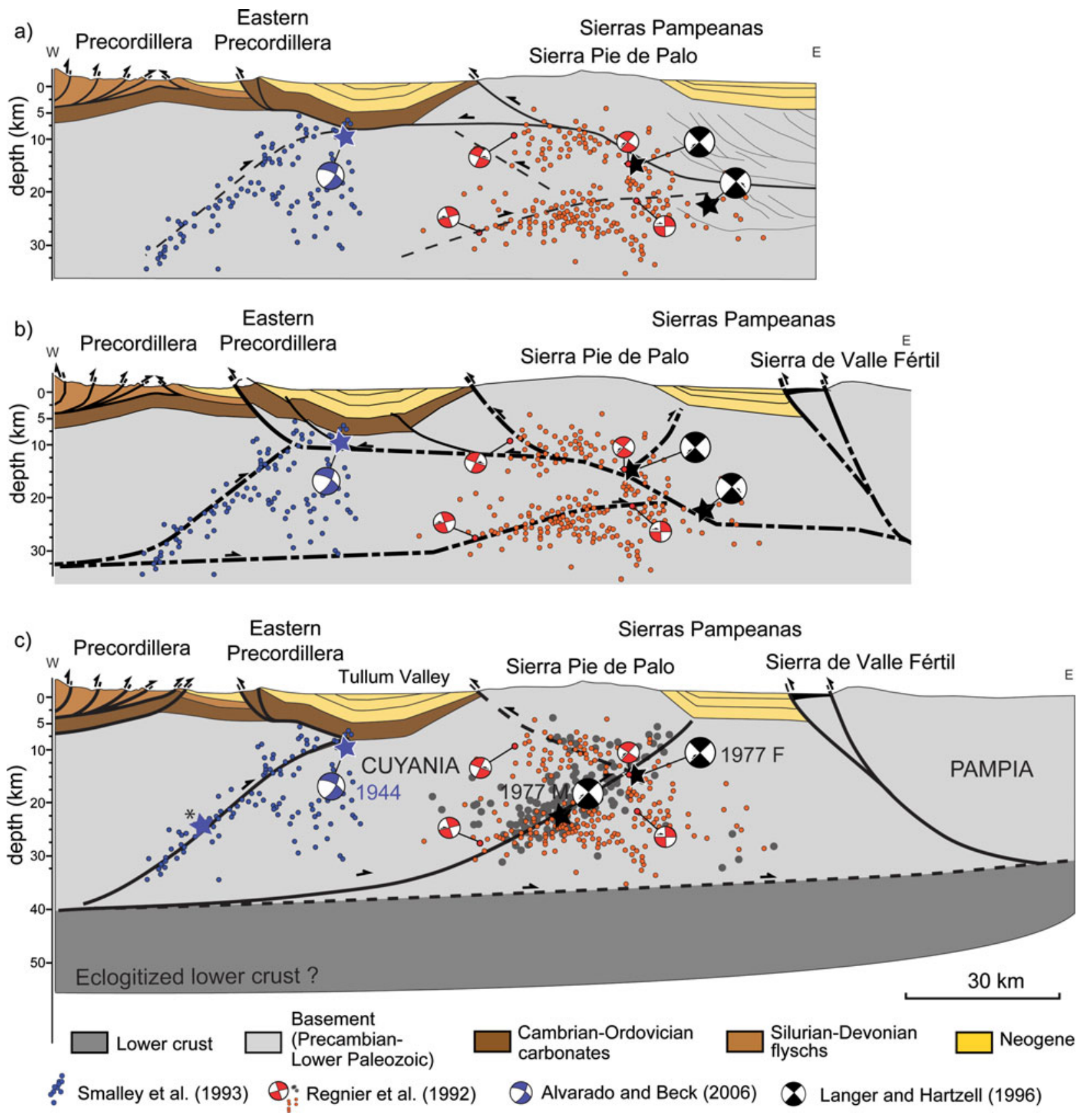

Figure 14. (Colour online) Crustal-scale cross-section of the Sierra Pie de Palo, the Sierra Valle Fértil and the Precordillera (see Fig. 1b for location). (a) From Vergés et al. (2007); (b) in Siame et al. (2015); and (c) this study. In (c), the front of the Precordillera has been modified after Alonso et al. (2014). The asterisk near the star along the western crustal E-verging thrust represents an alternative solution for the 1944 focus (from Meigs and Nabelek, 2010). The 1977M earthquake focus have been translated $30 \mathrm{~km}$ to the west as suggested in Regnier et al. (1992).

the formation of small reverse faults, the foliation being not parallel to the basement/cover interface. Such interpretation has also been proposed for other Andean structures (e.g. Alonso et al. 2005). Alternatively, these small structures may also be due to intercutaneous wedge processes. However, in both cases the resulting crustal thrust should be E-verging. It is noteworthy that an E-verging blind thrust below the Sierra Pie de Palo is opposite to the main kinematics of the Pampean province.

According to seismological data, we consider here that the E-verging blind thrust below the Sierra Pie de Palo should root at the base or below the upper seismogenic crust, i.e. at $\sim 40 \mathrm{~km}$ (Fig. 14c) as already proposed by Siame et al. (2015) for a slightly different structural interpretation (Fig. 14b). In our model, the thrust to the SW of the Sierra Pie de Palo (Tulum Fault) is considered as a back thrust branched at depth on the main E-verging thrust. This configuration is in agreement with the seismicity (Figs 13, 14), especially considering that the 1977 earthquake should be located $30 \mathrm{~km}$ west (Fig. 14c) of its initial location (Fig. 14a, b) as stated in Regnier et al. (1992). The $20^{\circ} \mathrm{E}$ dip of the erosional surface (backlimb west of the Tulum 


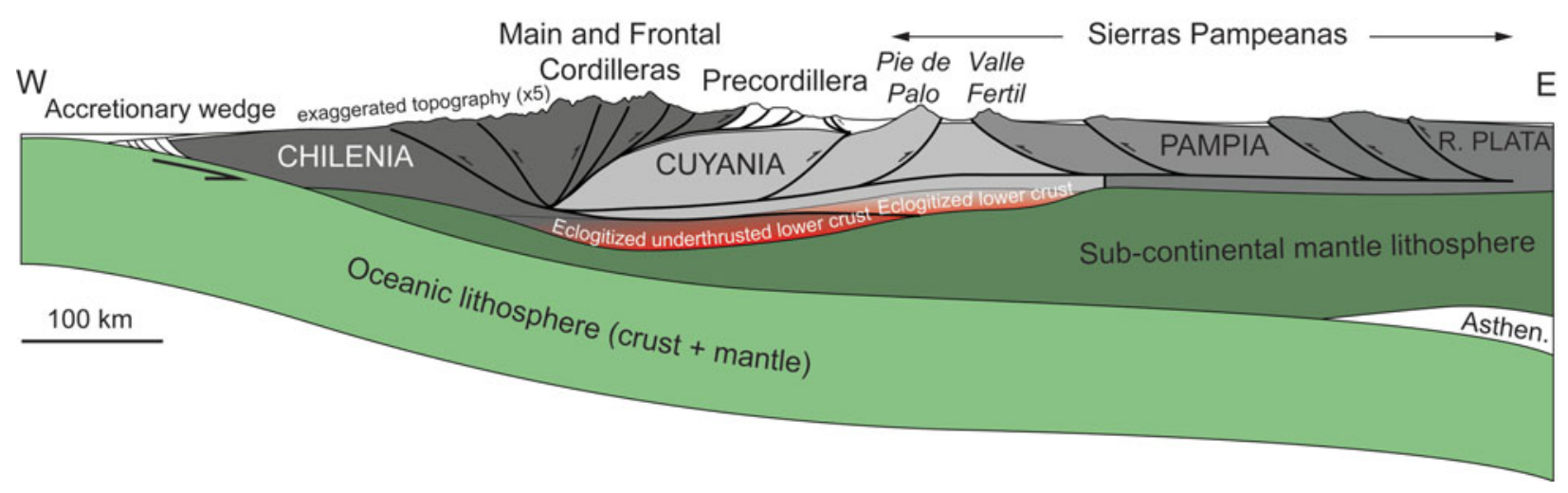

Figure 15. (Colour online) Lithospheric-scale section of the Andes modified from Cristallini and Ramos (2000) (see Fig. 1a for location). The crustal structure at Pie de Palo and below the Precordillera were modified according to the present study. The Moho and lower crustal structure (eclogitized root) are from Ammirati et al. (2013) and Ammirati, Alvarado \& Beck (2015). The Eastern Sierras Pampeanas structure is from Ramos et al. (2002) and Perarnau et al. (2012).

W-verging thrust, below the Neogene sediments of the Tulum valley; Figs 2, 13a, 14) thus approximately represents the dip of the E-verging thrust at depth, consistent with the model of fault-propagation fold.

The E-verging thrust ramps off a deep crustal décollement (either at the base of the seismogenic crust or in the lower crust; Fig. 14c) as well as the E-verging basement thrust that activated the Eastern Precordillera (Meigs et al. 2006). This Precordillera is W-verging because of the change of vergence in the décollement at the base of the cover (Fig. 14c). This is consistent with the interpretation of Vergés et al. (2007), Meigs et al. (2006) and Rockwell et al. (2014), if we consider that the 1944 earthquake is due to a displacement at the cover base where the thrust vergence changes (Fig. 14c) at 9-11 km (Alvarado \& Beck, 2006; Meigs et al. 2006). Alternatively, this 1944 earthquake could have ruptured deeper $(\sim 25 \mathrm{~km})$ on the E-verging basement ramp (Meigs \& Nabelek, 2010), which is located below the Eastern Precordillera (Smalley et al. 1993) (Fig. 14c).

These two E-verging structures, which are located below the Eastern Precordillera and the Pie de Palo Anticline, stand between the thin-skinned Western and Central Precordillera to the west and the Pampean Wverging Sierra de Valle Fértil to the east. It is noteworthy that the crust below the Sierra Pie de Palo and the Valle Fértil is considered as different (e.g. Ramos, 2004): the crust below Valle Fértil and further east is Pampia, while below Sierra Pie de Palo and the Precordillera it is Cuyania. Thus, there might be a link between these different crusts and the different vergences in these domains: in the Cuyania domain, the thrusts are E-verging at the surface (except in the Eastern Precordillera) while in the Pampia crust the thrusts appear predominantly W-verging.

\section{6.b. Lithospheric structure}

In the North American Laramide province of the Rocky Mountains, the presence of large basement uplift (sim- ilar to the Sierras Pampeanas; e.g. Jordan \& Allmendinger, 1986) is probably due to subcrustal shear, crustal buckling and faulting above a décollement in the lower crust, or crustal buckling and faulting superimposed on a lithosphere buckling (Erslev, 2005; Yonkee \& Weil, 2015; see a synthesis in Lacombe \& Bellahsen, 2016). In all cases, the driving force arises from the push of a flat slab transmitting stresses far in the interior of the overriding plate. In the Andean foreland of NW Argentina, both vergences are found in the mountain range and are most likely controlled by inherited structures (Ramos, Cristallini \& Pérez, 2002).

The E-verging thrusts beneath the Sierra Pie de Palo and the Eastern Precordillera could be considered as a 'normal kinematics': they are the eastward thickskinned propagation at depth of the E-verging thinskinned system of the Precordillera. As classically considered, the flat slab geometry induced stresses to be propagated further down in the crust and to the east. The W-verging Pampean structures (such as Valle Fértil) are strongly controlled by structural inheritance, i.e. E-dipping inherited Triassic normal faults that are reactivated during the Neogene and Quaternary (Ramos, Cristallini \& Pérez, 2002).

The Cuyania crust below the Sierra Pie de Palo is very thick $(52-60 \mathrm{~km})$, while the thickness of the Pampean crust, further east, decreases eastward from $\sim 50 \mathrm{~km}$ to $35 \mathrm{~km}$ (Ammirati et al. 2013; Ammirati, Alvarado \& Beck, 2015). Moreover, these authors interpreted the Cuyania lower crust as eclogitized. As the shortening is rather low in this region (Fig. 13), it cannot only explain the eclogitization; it should rather result from the initial thickness of the Cuyania crust. Thus, it is likely that Cuyania was already quite thick, at least in its eastern part, before the Neogene shortening.

Below the Precordillera, the crust is thicker ( $\sim 65 \mathrm{~km}$; e.g. Ammirati et al. 2013). Considering the amount of shortening in the Precordillera $(135 \mathrm{~km})$, the Cuyania crust must have been significantly underthrusted below the Andean Cordillera, i.e. below the Chilenia upper crust (Cristallini \& Ramos, 2000). Thus, it is 
likely that, for balancing purpose, the Chilenia lower crust was underthrusted below Cuyania (Cristallini \& Ramos, 2000) (Fig. 15). This process is coeval with the Tertiary formation of the Principal and Frontal Cordilleras as well as the Western and Central Precordilleras. During this process, the Chilenia lower crust was possibly eclogitized as well as the Cuyania lower crust further east.

When the slab dip decreased, at $c .10 \mathrm{Ma}$, the stresses were transferred to the Cuyania and Pampia crust. It is noteworthy that it may also correspond to the period when the crust below the Cordillera and Precordillera became too thick and too strong because of its eclogitized root. The shortening propagated through a deep décollement between the seismogenic crust and the eclogitized root, in the Cuyania crust at $\sim 40 \mathrm{~km}$ depth, and furthermost to the Sierra de Córdoba region within the Pampia / Río de la Plata crusts at c. $35 \mathrm{~km}$ depth.

\section{Conclusions}

We have investigated the small $\mathrm{W}$-verging reverse faults along the eastern side of the Sierra Pie de Palo anticline. We showed that these faults are less than $8 \mathrm{~km}$ long and have displacement of a few hundred metres. These faults are thus relatively shallow and can hardly root in the deep crust as previously proposed (e.g. Ramos, Cristallini \& Pérez, 2002). These faults show typical brittle structures in the basement. They initiated in the basement by shearing along inherited weak foliation levels or inherited shear zones, particularly within mica-rich layers, inducing a small-scale folding of quartzo-feldspathic layers, and subsequently their brecciation. They evolved as thrust faults propagating in the Neogene cover as thrusts or folds, and are even faulting Quaternary strath terraces.

These faults, which are only seen along the eastern side of the Sierra Pie de Palo, may attest for basement folding at crustal scale, with foliation-parallel slip as folding mechanism, although alternative models may also be considered. The highly deformed eastern Sierra Pie de Palo most likely represents a forelimb and thus suggests for E-verging blind thrust at depth. This vergence is opposite to the common Pampean vergence but may be considered typical for Cuyania crust.

Such E-verging thrust may be rooting at depth westward beneath the Andean Cordillera (as well as the other Pampean W-verging thrusts, linked through a mid- to lower-crustal décollement) where the Chilenia lower crust is underthrusted and eclogitized below the Cuyania crust.

Acknowledgements. This work was done within a joint programme between ISTeP (Sorbonne University - University Pierre and Marie Curie, Paris) and CEREGE (Aix-enProvence). SPOT images were provided by the TectoscopeAndes and ISIS programmes (CNES/INSU/CNRS). We thank the ECOS-SUD programme for travel grants made to N. Bellahsen, M. Sebrier and L. Siame for field work in Argentina. We are indebted to Carlos Costa (Universidad Nacional de San Luis) for logistical help and many discus- sions on the geology of the Sierra Pampeanas and Argentina in general. We also thank E. Ahumada and H. Cisneros for invaluable help during fieldwork and J. L. Alonso and an anonymous reviewer for comments that greatly improved the initial version of the manuscript.

\section{References}

Allmendinger, R. W., FigueroA, D., Snyder, D., BeER, J., MPODOZIS, C. \& ISACKS, B. L. 1990. Foreland shortening and crustal balancing in the Andes at $30^{\circ} \mathrm{S}$ latitude. Tectonics 9, 789-809.

Alonso, J. L., Gallastegui, J., Rodriguez Fernandez, L. R. \& J., GARCIA-SANSEGUNDO 2014. Stratigraphy and structure of the Punta Negra Anticline. Implications on the structural evolution of the Argentine Precordillera. Journal of Iberian Geology 40(2), 283.

ALONSO, J. L. 1989. Fold reactivation involving angular unconformable sequences: theoretical analysis and natural examples from the Cantabrian zone (northwest Spain). Tectonophysics 170, 57-77.

Alonso, J. L., RoDriguez_FERnANDEZ, L. R., GARCIASAnsegundo, J., Heredia, N., FARIAS, P. \& GALlASTEGUI, J. (2005). Gondwanic and Andean structure in the Argentine Central Precordillera: the Río San Juan section revisited. In 6th International Symposium on Andean Geodynamics, Extended Abstracts. Paris: IRD Editions, 36-9.

AlvarAdo, P. \& BECK, S. 2006. Source characterization of the San Juan (Argentina) crustal earthquakes of 15 January 1944 (Mw 7.0) and 11 June 1952 (Mw 6.8). Earth and Planetary Science Letters 243(3-4), 615-31.

Alvarado, P., BeCK, S. \& ZANDT, G. 2007. Crustal structure of the south-central Andes Cordillera and backarc region from regional waveform modelling. Geophysical Journal International 170(2), 858-75.

Alvarado, P., Beck, S., Zandt, G., Araujo, M. \& TrieP, E. 2005. Crustal deformation in the south-central Andes backarc terranes as viewed from regional broad-band seismic waveform modelling. Geophysical Journal International 163(2), 580-98.

Alvarado, P., Pardo, M., Gilbert, H., Miranda, S., ANDERSON, M., SAEZ, M. \& BeCK, S. 2009. Flat-slab subduction and crustal models for the seismically active Sierras Pampeanas region of Argentina. In Backbone of the Americas: Shallow Subduction, Plateau Uplift, and Ridge and Terrane Collision (eds S. Mahlburg Kay, V. A. Ramos \& W. R. Dickinson), pp. 261-78. Geological Society of America Memoir no. 204.

Ammirati, J.-B., Alvarado, P. \& Beck, S. 2015. A lithospheric velocity model for the flat slab region of Argentina from joint inversion of Rayleigh wave phase velocity dispersion and teleseismic receiver functions. Geophysical Journal International 202(1), 224-41.

Ammirati, J.-B., Alvarado, P., Perarnau, M., Saez, M. \& Monsalvo, G. 2013. Crustal structure of the Central Precordillera of San Juan, Argentina $\left(31^{\circ} \mathrm{S}\right)$ using teleseismic receiver functions. Journal of South American Earth Sciences 46, 100-9.

Anderson, M., Alvarado, P., ZANDT, G. \& Beck, S. 2007. Geometry and brittle deformation of the subducting Nazca plate, Central Chile and Argentina. Geophysical Journal International 171(1), 419-34.

BeAudoin, N., LePrÊtre, R., BELlahsen, N., LACOMBE, O., AMrouch, K., CALlot, J.-P., EMmanUel, L. \& DANiEL, J.-M. 2012. Structural and microstructural evolution of the Rattlesnake Mountain Anticline (Wyoming, USA): 
new insights into the Sevier and Laramide orogenic stress build-up in the Bighorn Basin. Tectonophysics 576-577, 20-45.

Bos, B. \& SPIERS, C. J. 2001. Experimental investigation into the microstructural and mechanical evolution of phyllosilicate-bearing fault rock under conditions favouring pressure solution. Journal of Structural Geology 23(8), 1187-202.

Bos, B. \& SPIERS, C. J. 2002. Frictional-viscous flow of phyllosilicate-bearing fault rock: microphysical model and implications for crustal strength profiles. Journal of Geophysical Research 107(B2), 2028. doi: 10.1029/2001JB000301.

Brooks, B. A., Bevis, M., Smalley, R., Kendrick, E., Manceda, R., Lauría, E., Maturana, R. \& Araujo, M. 2003. Crustal motion in the Southern Andes (26 ${ }^{\circ}$ $\left.36^{\circ} \mathrm{S}\right)$ : do the Andes behave like a microplate? Geochemistry, Geophysics, Geosystems 4(10), 1085. doi: 10.1029/2003GC000505.

BuMP, A. P. 2003. Reactivation, trishear modeling, and folded basement in Laramide uplifts: implications for the origins of intracontinental faults. GSA Today 13(3), 410.

CAHILL, T. \& ISACKS, B. L. 1992. Seismicity and shape of the subducted Nazca plate. Journal of Geophysical Research 97(B12), 17503-29.

Calkins, J. A., Zandt, G., Gilbert, H. J. \& Beck, S. L. 2006. Crustal images from San Juan, Argentina, obtained using high frequency local event receiver functions. Geophysical Research Letters 33(7), L07309. doi: 10.1029/2005GL025516.

Carignano, C., Cioccale, M. \& Rabassa, J. 1999. Landscape antiquity of the Central-Eastern Sierras Pampeanas (Argentina): geomorphological evolution since Gondwanic times. Zeitschrift für Geomorphologie Supplement 118, 245-68.

Casas, A., Oliva, B., Roman-Berdiel, T. \& Pueyo, E. 2003. Basement deformation: tertiary folding and fracturing of the Variscan Bielsa granite (Axial zone, central Pyrenees). Geodinamica Acta 16(2-6), 99-117.

Collettini, C., Niemeijer, A., Viti, C. \& Marone, C. 2009. Fault zone fabric and fault weakness. Nature 462(7275), 907-10.

Collo, G., DÁvila, F. M., Teixeira, W., Nóbile, J. C., SAN'T ANNA, L. \& CARTER, A. 2015. Isotopic and thermochronologic evidence of extremely cold lithosphere associated with a slab flattening in the Central Andes of Argentina. Basin Research September. doi: 10.1111/bre. 12163

Costa, C. H., GARdini, C. E., Diederix, H. \& Cortés, J. M. 2000. The Andean orogenic front at Sierra de Las Peñas-Las Higueras, Mendoza, Argentina. Journal of South American Earth Sciences 13(3), 287-92.

Cristallini, E. O. \& Ramos, V. A. 2000. Thick-skinned and thin-skinned thrusting in the La Ramada fold and thrust belt: crustal evolution of the High Andes of San Juan, Argentina (32 SL). Tectonophysics 317(3), 20535.

Cuerda, A., Varela, R. \& Iniguez, A. M. 1983. Secuencia salifera en el terciario de Nikisanga, Sierra Pie de Palo, Provincia de San Juan. Asociacion Geologica Argentina 38, 412-20.

DAVILA, F. M. \& CARTER, A. 2013. Exhumation history of the Andean broken foreland revisited. Geology 41(4), 443-6.

DeMets, C., Gordon, R. G., Argus, D. F. \& Stein, S. 1990. Current plate motions. Geophysical Journal International 101(2), 425-78.
Enkelmann, E., Ridgway, K. D., Carignano, C. \& LINNEMANN, U. 2014. A thermochronometric view into an ancient landscape: tectonic setting, development, and inversion of the Paleozoic eastern Paganzo basin, Argentina. Lithosphere 6(2), 93-107.

ERSLEV, E. A. 1991. Trichear fault-propagation folding. Geo$\log y$ 19, 617-20.

ERSLEV, E. A. 2005. 2D Laramide geometries and kinematics of the Rocky Mountains, western USA. In The Rocky Mountain Region: An Evolving Lithosphere. Tectonics, Geochemistry, and Geophysics (eds K. E. Kalstrom \& G. R. Keller), pp. 7-20. Geophysical Monograph Series 154.

GARCIA, P. E. \& DAVIS, G. H. 2004. Evidence and mechanisms for folding of granite, Sierra de Hualfn basement-cored uplift, northwest Argentina. AAPG Bulletin 88(9), 1255-76.

Gutscher, M.-A., MAury, R., EISSEN, J.-P. \& Bourdon, E. 2000. Can slab melting be caused by flat subduction? Geology 28, 353-538.

Handy, M. R., Hirth, G. \& Hovius, N. 2007. Continental fault structure and rheology from the frictional-toviscous transition downward. In Tectonic Faults: Agents of Change on a Dynamic Earth (eds M. R. Handy, G. Firth \& N. Hovius), pp. 140-81. Cambridge, MA: MIT Press.

Holdsworth, R. E., van Diggelen, E. W. E., Spiers, C. J., DE BRESSER, J. H. P., WALKER, R. J. \& BOWEN, L. 2011. Fault rocks from the SAFOD core samples: implications for weakening at shallow depths along the San Andreas Fault, California. Journal of Structural Geology 33(2), 132-44.

Jefferies, S. P., Holdsworth, R. E., WibBerley, C. A. J., Shimamoto, T., Spiers, C. J., Niemeijer, A. R. \& LLOYD, G. E. 2006. The nature and importance of phyllonite development in crustal-scale fault cores: an example from the Median Tectonic Line, Japan. Journal of Structural Geology 28(2), 220-35.

JordAn, T. E. \& AllmendingER, R. W. 1986. The Sierras Pampeanas of Argentina: a modern analogue of Rocky Mountain foreland deformation. American Journal of Science 286, 737-64.

Jordan, T. E., Allmendinger, R. W., DAmanti, J. F. \& DRAKE, R. E. 1993. Chronology of motion in a complete thrust belt: the Precordillera, 30-31 ${ }^{\circ} \mathrm{S}$, Andes Mountains. Journal of Geology 101, 135-56.

JORDAN, T. E., ISACKS, B. L., RAMOS, V. A. \& AlLmendingeR, R. W. 1983. Mountain building in the Central Andes. Episodes 3, 20-6.

JordAN, T. E., SCHLUNEGGER, F. \& CARDOZO, N. 2001. Unsteady and spatially variable evolution of the Neogene Andean Bermejo foreland basin, Argentina. Journal of South American Earth Sciences 14(7), 775-98.

Jordan, T. E., Zeitler, P., Ramos, V. \& Gleadow, A. J. W. 1989. Thermochronometric data on the development of the basement peneplain in the Sierras Pampeanas, Argentina. Journal of South American Earth Sciences 2(3), 207-22.

KADINSKY-CADE, K. \& REILINGER, R. 1985. Surface deformation associated with the November 23, 1977, Caucete, Argentina, earthquake sequence. Journal of Geophysical Research 90, 12,691-700.

KAY, S. M. \& ABBRUZZI, J. M. 1996. Magmatic evidence for Neogene lithospheric evolution of the central Andean 'flat-slab' between $30^{\circ} \mathrm{S}$ and $32^{\circ} \mathrm{S}$. Tectonophysics $\mathbf{2 5 9}$, $15-28$.

KAY, S. M. \& MPODOZIS, C. 2002. Magmatism as a probe to the Neogene shallowing of the Nazca plate beneath the 
modern Chilean flat-slab. Journal of South American Earth Sciences 15, 39-57.

LACOMBE, O. \& Bellahsen, N. 2016. Thick-skinned tectonics and basement-involved fold-thrust belts: insights from selected Cenozoic orogens. Geological Magazine 152. doi: $10.1017 / \mathrm{S} 0016756816000078$ (this issue).

LANGER, C. J. \& BOLLINGER, 1988. Aftershocks of the western Argentina (Caucete) earthquake of 23 November 1977: some tectonic implications. Tectonophysics $\mathbf{1 4 8 ,}$ $131-46$.

LANGER, C. J. \& HARTZELL, S. 1996. Rupture distribution of the 1977 western Argentina earthquake. Physics of the Earth and Planetary Interiors 94(1), 121-132.

LÖBENS, S., BENSE, F. A., DUNKL, I., WeMMER, K., KLEY, J. \& SIEGESMUND, S. 2013. Thermochronological constraints of the exhumation and uplift of the Sierra de Pie de Palo, NW Argentina. Journal of South American Earth Sciences 48, 209-19.

LÖBens, S., Bense, F. A., WeMmer, K., DunKL, I., Costa, C. H., LAYER, P. \& SiegeSMUND, S. 2011. Exhumation and uplift of the Sierras Pampeanas: preliminary implications from $\mathrm{K}-\mathrm{Ar}$ fault gouge dating and low-T thermochronology in the Sierra de Comechingones (Argentina). International Journal of Earth Sciences 100(2-3), 671-94.

MACKAY, P. A., VARSEK, J. L., Kubli, T. E., DeCheSne, R. G., Newson, A. C. \& REID, J. P. 1996. Triangle zones and tectonic wedges: an introduction. Bulletin of Canadian Petroleum Geology 44, 1-5.

Meigs, A., Krugh, W. C., Schiffman, C., Vergés, J., RAMOS, V. A. \& others 2006. Refolding of thin-skinned thrust sheets by active basement-involved thrust faults in the eastern Precordillera of western Argentina. Revista de la Asociación Geológica Argentina 61(4), 589-603.

MeIgS, A. J. \& NABELEK, J. 2010. Crustal-scale pure shear foreland deformation of western Argentina. Geophysical Research Letters 37(11), L11304. doi: 10.1029/2010GL043220.

Mulcahy, S. R., Roeske, S. M., McClelland, W. C., Jourdan, F., IrIONDO, A., RENNE, P. R., VerVoORT, J. D., \& VuJovich, G. I. 2011. Structural evolution of a composite middle to lower crustal section: the Sierra de Pie de Palo, northwest Argentina, Tectonics 30. doi:10.1029/2009TC002656.

NiemeiJer, A., MARONe, C. \& Elsworth, D. 2010. Fabric induced weakness of tectonic faults. Geophysical Research Letters 37(3), L03304. doi: 10.1029/2009GL041689.

NIEMEIJER, A. R. \& SPIERS, C. J. 2005. Influence of phyllosilicates on fault strength in the brittle-ductile transition: insights from rock analogue experiments. In High-Strain Zones: Structure and Physical Properties (eds D. Bruhn \& L. Burlini), pp. 303-27. Geological Society of London Special Publication no. 245.

Perarnau, M., Gilbert, H., Alvarado, P., Martino, R. \& ANDERSON, M. 2012. Crustal structure of the Eastern Sierras Pampeanas of Argentina using high frequency local receiver functions. Tectonophysics 580, 20817.

PILGER, R. H. 1981. Plate reconstructions, aseismic ridges, and low-angle subduction beneath the Andes. Geological Society of America Bulletin 92, 448-56.

Rabassa, J. C., CARignano, C. \& Cioccale, M. 2010. Gondwana paleosurfaces in Argentina: an introduction. Geociencas 4, 439-66.

RAmos, V. A. 2004. Cuyania, an exotic block to Gondwana: review of a historical success and the present problems. Gondwana Research 7, 1-18.
Ramos, V. A., Cristallini, E. O. \& Pérez, D. J. 2002. The Pampean flat-slab of the Central Andes. Journal of South American Earth Sciences 15(1), 59-78.

Ramos, V. A. \& Vujovich, G. 2000. Hoja Geológica San Juan, escala 1:250.000. Buenos Aires: Servicio Geológico Minero Argentino.

Regnier, M., Chatelain, J. L., Smalley, R., Chiu, J.-M., ISACKS, B. L. \& ARAUJO, M. 1992. Seismotectonics of Sierra Pie de Palo, a basement block uplift in the Andean foreland of Argentina. Bulletin of the Seismological Society of America 82(6), 2549-71.

REILINGER, R. \& KADINSKY-CADE, K. 1985. Earthquake deformation cycle in the Andean back arc, Western Argentina. Journal of Geophysical Research 90, 12,701-12.

Rockwell, T. K., Ragona, D. E., Meigs, A. J., Owen, L. A., Costa, C. H. \& Ahumada, E. A. 2014. Inferring a thrust-related earthquake history from secondary faulting: a long rupture record of La Laja Fault, San Juan, Argentina. Bulletin of the Seismological Society of America 104(1), 269-84.

Schmidt, C. J., Genovese, P. W. \& Chase, R. B. 1993. Role of basement fabric and cover-rock lithology on the geometry and kinematics of twelve folds in the Rocky Mountain foreland. In Laramide Basement Deformation in the Rocky Mountain Foreland of the Western United States (eds C. J. Schmidt, R. B. Chase \& E. A. Erslev), pp. 1-44. Geological Society of America Special Paper 280.

SchOLZ, C. H. 2002. The Mechanics of Earthquakes and Faulting, 2nd edn. Cambridge: Cambridge University Press, $471 \mathrm{pp}$.

Sebrier, M., Mercier, J.-L., Macharé, J., Bonnot, D., CABRERA, J. \& BLANC, J.-L. 1988. The state of stress in an overriding plate sitiuated above a flat slab: the Andes of Central Peru. Tectonics 7, 895-928.

ShEA, W. T. \& KronenberG, A. K. 1992. Rheology and deformation mechanisms of an isotropic mica schist. Journal of Geophysical Research: Solid Earth 97(B11), 15,201-37.

SheA, W. T. \& KronenberG, A. K. 1993. Strength and anisotropy of foliated rocks with varied mica contents. Journal of Structural Geology 15, 1097-121.

SiAme, L. L., Bellier, O. \& SEBrier, M. 2006. Active tectonics in the Argentine Precordillera and western Sierras Pampeanas. Revista de la Asociación Geológica Argentina 61(4), 604-19.

Siame, L. L., Bellier, O., Sebrier, M. \& Araujo, M. 2005. Deformation partitioning in flat subduction setting: case of the Andean foreland of western $\mathrm{Ar}$ gentina $\left(28^{\circ} \mathrm{S}-33^{\circ} \mathrm{S}\right)$. Tectonics 24(5), TC5003. doi: 10.1029/2005TC001787.

Siame, L. L., Bellier, O., Sebrier, M., Bourlès, D., Leturmy, P., Perez, M. \& Araujo, M. 2002. Seismic hazard reappraisal from combined structural geology, geomorphology and cosmic ray exposure dating analyses: the Eastern Precordillera thrust system (NW Argentina). Geophysical Journal International 150, 24160 .

Siame, L. L., Sebrier, M., Bellier, O., Bourlès, D., Costa, C., Ahumada, E. A., Gardini, C. E. \& Cisneros, H. 2015. Active basement uplift of Sierra Pie de Palo (Northwestern Argentina): rates and inception from ${ }^{10} \mathrm{Be}$ cosmogenic nuclide concentrations. Tectonics 34(6), 1129-53.

Smalley, R. J., Pujol, J., Regnier, M., Chiu, J.-M., Chatelain, J. L., Isacks, B. L., Araujo, M. \& Puebla, N. 1993. Basement seismicity beneath the Andean Precordiellera thin-skinned thrust belt and implications 
for crustal and lithopsheric behavior. Tectonics 12, 6376.

SupPE, J. \& MedwedefF, D. A. 1990. Geometry and kinematics of fault-propagation folding. Eclogae Geologicae Helvetiae 83(3), 409-54.

Van StaAl, C. R., Vujovich, G. I., Currie, K. L., et al. 2011. An Alpine-style Ordovician collision complex in the Sierra de Pie de Palo, Argentina: record of subduction of Cuyania beneath the Famatina arc. Journal of Structural Geology 33(3), 343-61.

Vergés, J., Ramos, V. A., Meigs, A., Cristallini, E., BETTINI, F. H. \& CORTÉS, J. M. 2007. Crustal wedging triggering recent deformation in the Andean thrust front between $31^{\circ} \mathrm{S}$ and $33^{\circ} \mathrm{S}$ : Sierras PampeanasPrecordillera interaction. Journal of Geophysical Research 112(B3), B03S15. doi: 10.1029/2006JB004287.

Yanez, G. A., Ranero, C. R., von Huene, R. \& Diaz, J. 2001. Magnetic anomaly interpretation across the southern central Andes $\left(32^{\circ}-34^{\circ} \mathrm{S}\right)$ : the role of the Juan
Fernandez Ridge in the late Tertiary evolution of the margin. Journal of Geophysical Research 106, 632545.

YonkeE, W. A. \& WeIL, A. B. 2015. Tectonic evolution of the Sevier and Laramide belts within the North American Cordillera orogenic system. Earth-Science Reviews 150, 531-93.

ZAmbrano, J. \& Suvires, G. M. 2008. Actualización en el limite entre sierras Pampeanas occidentales y Precordillera Oriental, en la provincia de San Juan. Revista de la Asociación Geológica Argentina 63, 110-6.

ZAPATA, T. R. 1998. Crustal structure of the Andean thrust front at $30^{\circ} \mathrm{S}$ latitude from shallow and deep seismic reflection profiles, Argentina. Journal of South American Earth Sciences 11, 131-51.

ZAPATA, T. R. \& ALLMENDINGER, R. W. 1996. Growth stratal records of instantaneous and progressive limb rotation in the Precordillera thrust belt and Bermejo basin, Argentina. Tectonics 15, 1065-83. 